\title{
The Effect of Alternative Pruning Methods on the Viticultural and Oenological Performance of Some Wine Grape Varieties
}

\author{
E. Archer ${ }^{1}$ and D. van Schalkwyk ${ }^{2 *}$
}

(1) Lusan Premium Wines, PO Box 104, 7599 Stellenbosch, South Africa

(2) ARC Infruitec-Nietvoorbij, Private Bag X5026, 7599 Stellenbosch, South Africa

Submitted for publication: March 2007

Accepted for publication: May 2007

Key words: Grapevine, pruning, wine quality

\begin{abstract}
Three different trials, at three different localities, each with different growing conditions, were conducted with nine different wine grape varieties. Four different pruning methods, hand, mechanical, minimal and no pruning were tested. Growth responses, grape composition and morphology, wine quality as well as labour inputs were evaluated. Huge labour savings were obtained with the alternative pruning methods compared to hand pruning. A reduction in vigour and increase in yield were evident in each variety. Wine quality was not decreased and in some cases even a quality increase was evident. Varieties differ in their adaptability to alternative pruning methods with Cabernet Sauvignon, Pinotage and Chardonnay performing well and Sauvignon blanc and Merlot poorly. Chenin blanc, Shiraz, Colombar and Ruby Cabernet showed acceptable performance. Alternative pruning methods proved to be viable, especially for the production of medium and low priced wines.
\end{abstract}

\section{INTRODUCTION}

Rising production costs in the national and international wine industries essentialise the implementation of cost reducing methods and procedures. Labour costs are responsible for more than $60 \%$ of total annual costs of wine grape production in South Africa (Vinpro, 2005) and, therefore, the development of labour saving techniques is of paramount importance. Most wine grape vineyards in the Western Cape are pruned by hand. This makes an important contribution to the annual labour costs of producing wine grapes and, therefore alternative pruning methods had to be investigated. These alternative pruning methods are mechanical spur pruning (May \& Clingeleffer, 1977; Clingeleffer, 1988), minimal pruning (Clingeleffer, 1993) and non-pruning (d'Armailhacq, 1867; Bakonyi, 1987).

Most reports on mechanical spur pruning showed an increase in yield (Morris et al., 1975; May \& Clingeleffer, 1977; Clingeleffer, 1988; Reynolds, 1988; Reynolds \& Wardle, 1993; Archer, 1999). On the other hand, it reduced bunch and berry mass (Morris et al., 1975; Morris et al., 1981; Reynolds, 1988), and sugar concentration (Shaulis et al, 1973; Morris \& Cawthon, 1980 and 1981; Anderson et al., 1996). In general, wine quality was reduced mainly due to a loss in colour with red grapes (Reynolds \& Wardle, 1993). The response of the vine to mechanical spur pruning varied according to cultivar (McCarthy \& Cirami, 1990) as well as clone (Clingeleffer, 1988; McCarthy \& Cirami, 1990) and virus infection (Clingeleffer \& Krake, 1992; Rühl \& Clingeleffer, 1993).

Research results on minimal pruning, compared to normal hand pruning, showed an increase in yield, number of bunches and shoots (Cirami et al, 1985; Clingeleffer \& Possingham, 1987; Clingeleffer, 1988 and 1989; McCarthy \& Cirami, 1990;
Clingeleffer, 1993). Most of these reports showed that sugar concentration, as well as $\mathrm{pH}$ were reduced and total acid concentration increased by minimal pruning. In terms of wine colour, flavour and quality, variable results were reported depending on climate and vigour.

Research results on non-pruning are not abundant. Working with seven different cultivars, Bakonyi (1987) reported increased yields, no obvious loss in quality but an increase in oïdium and vine scales compared to hand pruned control vines. The research of Martinez de Toda \& Sancha (1988) on un-irrigated Grenache showed that non-pruning increased the yield, dry matter and sugar production per vine. This was ascribed to a significant increase in total leaf area per vine. On the other hand, sugar concentration was reduced.

Although general trends in the effect of alternative pruning methods on grapevine performance are visible from the research results, the following pertinent questions needed answers under the specific viticultural conditions prevailing in South Africa: 1) Can these methods be used in producing top quality red wine from a noble cultivar? 2) Are these methods applicable under different climatic conditions? 3) Are there response differences between cultivars to these pruning methods? In an endeavour to answer these questions, this research project was undertaken in 1996.

\section{MATERIALS AND METHODS}

The project entailed three field trials at three different localities:

\section{Trial at Elsenburg}

The one ha trial vineyard was planted in 1996 on an Oakleaf soil form (Soil Classification Work Group, 1991) with six cultivars: Chardonnay, Chenin blanc, Sauvignon blanc, Pinotage, Shiraz and Cabernet Sauvignon, all grafted onto Richter 99 rootstock.

\footnotetext{
*Corresponding author:VSchalkwykD@arc.agric.za
}

Acknowledgements: The Wine Grape staff at Nietvoorbij is thanked for their technical assistance. Winetech and ARC Infruitec-Nietvoorbij are thanked for their financial support. New Holland South Africa and Unique Agri Trade are thanked for harvesting the alternative pruning treatments of the Cabernet Sauvignon trial at Nietvoorbij with Braud and Gregiore mechanical harvesters, respectively. 
The treatments used were: control (hand pruned to two-bud spurs, 12 spurs per vine), mechanical pruning (vines were pruned with mechanical hedge cutters approximately $10 \mathrm{~cm}$ above the cordon; no thinning of spurs were done) and minimal pruning (vines were mechanical skirted approximately $30 \mathrm{~cm}$ above ground level during December and the sides were trimmed with mechanical hedge cutters to keep the rows open for spraying. The tops were untouched). Both cultivars and pruning treatments were randomised in blocks and consisted of three replicates each separated by buffer rows.

Before planting the soil was criss-crossed with a shift delve plough to a depth of $1.2 \mathrm{~m}$ after $4.5 \mathrm{t} / \mathrm{ha}$ calcitic lime was broadcasted on the soil surface. This resulted in a soil $\mathrm{pH}$ of 5.2 to 5.9 and the vineyard was cultivated without irrigation. Vines in the control plots were split-cordon trained (cordon height above ground $=0.60 \mathrm{~m}$ ) on a standard four strand Perold trellis with movable foliage wires (Zeeman, 1981). Vines in the other plots were split-cordon trained (cordon height above ground $=1.20 \mathrm{~m}$ ) on a one strand Hedge trellis (Zeeman, 1981). Vine spacing in all cases was $3.0 \mathrm{~m} \times 1.5 \mathrm{~m}$, resulting in 222 vines/ha.

\section{Trial at Robertson}

This two ha trial vineyard was planted in 1997 on a Hutton soil form (Soil Classification Work Group, 1991) with six cultivars: Chardonnay, Chenin blanc, Colombar, Sauvignon blanc, Ruby Cabernet and Shiraz, all grafted onto Richter 99 rootstock. The treatments used were: control (hand pruned to two-bud spurs, 14 spurs per vine), mechanical pruning (vines were pruned with mechanical hedge cutters approximately $10 \mathrm{~cm}$ above the cordon; no thinning of spurs were done) and minimal pruning (vines were mechanical skirted approximately $30 \mathrm{~cm}$ above ground level during December and the sides were trimmed with mechanical hedge cutters to keep the rows open for spraying. The tops were untouched). Both cultivars and pruning treatments were randomised in blocks and consisted of six replicates, each separated by buffer rows. Based on heat summation over the growing period (September to March), this locality is in climatic region III (Saayman, 1981 ) at $33^{\circ} 55^{1}$ South latitude. Before planting, the soil was crisscrossed with a shift delve plough to a depth of $1.3 \mathrm{~m}$ after $6.5 \mathrm{t} /$ ha dolomitic lime was broadcasted on the soil surface (eventual soil $\mathrm{pH}=6.3$ ). Irrigation was applied by means of micro-jets and scheduled according to A-pan evaporation and crop factors. Vines in the control plots were split-cordon trained (cordon height above ground $=0.70 \mathrm{~m}$ ) on a standard five strand Perold trellis (Zeeman, 1981) with movable foliage wires. Vines in the other plots were split-cordon trained (cordon height above ground $=$ $1.20 \mathrm{~m}$ ) on a one strand hedge trellis (Zeeman, 1981). Vine spacing in all cases was $3.0 \mathrm{~m} \times 1.5 \mathrm{~m}$, resulting in 222 vines per ha. The nutrition programme was managed in the same way as with the trial at Elsenburg.

\section{Trial at Nietvoorbij}

This one ha trial was laid out in an existing Cabernet Sauvignon x Richter 99 vineyard on an Avalon soil form (Soil Classification work Group, 1991). Vine spacing was $2.75 \mathrm{~m} \mathrm{x} 1.5 \mathrm{~m}$ resulting in 2424 vine per ha, and the existing five strand Perold trellis as well as the vines (expect for the control plots) were converted to a high $(1.2 \mathrm{~m})$ one strand Hedge trellis according to the procedures described by Archer \& Van Schalkwyk (1998). The following treatments were applied: control (hand pruning to 12 two-bud spurs per vine), mechanical pruning (vines were pruned with mechanical hedge cutters approximately $10 \mathrm{~cm}$ above the cordon; no thinning of spurs were done) minimal pruning (vines were mechanical skirted approximately $30 \mathrm{~cm}$ above ground level during December and the sides were trimmed with mechanical hedge cutters to keep the rows open for spraying. The tops were untouched) and non-pruning (no pruning or trimming was applied). The pruning treatments were randomised in blocks and consisted of five replicates, each separated by buffer rows and vines.

Before planting, the soil was criss-crossed with a shift delve plough to depth of $1.30 \mathrm{~m}$ after $12 \mathrm{t} /$ ha calcitic lime was broadcasted on the soil surface (eventual soil $\mathrm{pH}=5.9$ ). Depending on the season and soil moisture measurements, a maximum of three irrigations were applied with micro-jets. Vines in the control plots were split-cordon trained (cordon height above ground $=0.70 \mathrm{~m}$ ). Vines in the other plots were trained exactly the same as in the trials at Elsenburg and Robertson.

\section{MEASUREMENTS}

\section{Time studies}

Time studies to determine man hours needed for each operation were done during pruning, canopy management (suckering, positioning of shoots, tipping, topping and leaf removal) and harvesting and from these the labour needed to manage the vines of each of the pruning systems was calculated (machine and machine operator costs not included).

\section{Yield, bunch mass, peduncle mass, berry mass and berry volume}

During harvest, the physical condition of the grapes was visually evaluated in all plots and the percentage rot, millerandage, etc. noted by the same person. Thirty vines per plot were harvested in crates, weighed, and the average yield per vine calculated. One crate per plot was randomly selected, weighed, and the number of bunches counted to calculate the average bunch mass. Five bunches from each of those crates were randomly selected and stored at $-20^{\circ} \mathrm{C}$ until after harvest to determine berry mass and volume. In the case of the trial at Nietvoorbij, five vines per plot were harvested to determine yield per vine, bunch, pedicel and berry mass as well as berry volume. The rest of the vines of the alternative pruned treatments were then mechanically harvested. The mass of the frozen berries was determined by being thawed. Using the methods as described by Van Schalkwyk (2004) to determine bunch mass, peduncle mass, berry mass and berry volume, five bunches of each plot were randomly sampled and the frozen berries rubbed off in such a way that the pedicel were left on the peduncles. Out of this sample, 100 berries were randomly counted and weighed using a laboratory balance with a sensitivity of two decimals per gram. These berries were also used to determine berry volume. A $1000 \mathrm{~mL}$ measuring cylinder was filled with enough water to cover 100 berries (e.g. $200 \mathrm{~mL}$ ). The berries were then added, a reading taken and the first reading subtracted from the second to determine the volume of 100 berries. All five bunches peduncles per sample were weighed after the berries were rubbed off and average mass calculated.

\section{Cane mass and number of buds}

During winter, the number of shoots per vine and internodes per shoot were counted. Cane length was measured using all the canes of five vines per replicate and the average internode length was 
calculated. To calculate the cane mass per vine, 30 vines of each replicate were of the hand and mechanically pruned treatments were weighed. In one year the number of winter buds were counted on five randomly selected vines per plot. The same vines were used to count the shoots during spring and from this \% bud burst was calculated.

\section{Berry skin, wine colour and phenols}

Berry skin (Hunter et al., 1991) and wine colour (Ribéreau-Gayon et al., 2000) were only analysed for the red varieties at A420 nm and A520 nm using a LKB Biochrom Ultraspec II E UV/Visibile Spectrophotometer. Total phenolic compounds were quantified using a HPLC (Ribéreau-Gayon et al., 2000).

\section{Wines}

At Elsenburg and Nietvoorbij wines were prepared from all three and five replicates, respectively of all the treatments of all the varieties. At Robertson grapes from replicates one and four, two and five, three and six, per treatment per variety were pooled respectively for wine making thus only three wines per treatment were made instead of six. Eighty $\mathrm{kg}$ of grapes were harvested per plot and used for wine making.

Grapes from the white varieties, Chardonnay, Chenin blanc, Colombar and Sauvignon blanc were harvested between $21.0^{\circ} \mathrm{B}$ to $22.0^{\circ} \mathrm{B}$ and red varieties, Cabernet Sauvignon, Merlot, Pinotage, Ruby Cabernet and Shiraz between $23.0^{\circ} \mathrm{B}$ to $24.0^{\circ} \mathrm{B}$, respectively.

Wines were made according to the standard Nietvoorbij procedure for small-scale winemaking at the ARC Infruitec-Nietvoorbij Research Institute. The vinification procedure for red wines was as follows: grapes were crushed, free $\mathrm{SO}_{2}$ content was adjusted to $50 \mathrm{mg} / \mathrm{L}$ before pressing and inoculated with VIN $13(30 \mathrm{~g} / \mathrm{hL})$ and fermented to $0^{\circ} \mathrm{B}$ at $24^{\circ} \mathrm{C}$. During this period the cap was punched down three times a day. The skins were separated from the juice using a pneumatic press and pressed juice added to the free-run juice. After fermentation was completed, the total $\mathrm{SO}_{2}$ content was adjusted to $85 \mathrm{mg} / \mathrm{L}$ and $50 \mathrm{~g} / \mathrm{hL}$ bentonite added. Wines were cold-stabilized for two weeks at $0^{\circ} \mathrm{C}$, filtered and bottled in $\mathrm{N}_{2}$-filled bottles at room temperature with adjustment of the total $\mathrm{SO}_{2}$ content to $85 \mathrm{mg} / \mathrm{L}$. The wines were stored in $750 \mathrm{~mL}$ bottles with screw-caps at $13^{\circ} \mathrm{C}$ in a dark, temperature-controlled room directly after bottling.

The vinification procedure for white wines was as follows: grapes from Chenin blanc and Colombar were crushed and the free-run juice collected. Total $\mathrm{SO}_{2}$ was adjusted to $50 \mathrm{mg} / \mathrm{L}$. The skins were separated from the juice using a pneumatic press and pressed juice added to the free-run juice. Overnight settling was allowed at $14^{\circ} \mathrm{C}$ after adding $0.5 \mathrm{~g} / \mathrm{hL}$ Ultrazyme. Clear juice was drawn off into $20 \mathrm{~L}$ stainless steal canisters and $50 \mathrm{~g} / \mathrm{hL}$ di-ammonium phosphate added and inoculated with VIN 13 (30 g/HL). Wines were dry fermented at $14^{\circ} \mathrm{C}$ at which point free $\mathrm{SO}_{2}$ was adjusted to $40 \mathrm{mg} / \mathrm{L}$, and $50 \mathrm{~g} / \mathrm{HL}$ bentonite added. Wines were cold stabilized at $0^{\circ} \mathrm{C}$ for at least one week, then racked and filtered trough filter sheets. Free $\mathrm{SO}_{2}$ was adjusted to $45 \mathrm{mg} / \mathrm{L}$ at bottling. The wines were stored in $750 \mathrm{~mL}$ bottles with screw-caps at $13^{\circ} \mathrm{C}$ in a dark, temperature-controlled room directly after bottling.

The same wine making procedures were followed for Chardonnay and Sauvignon blanc except that after crushing skin contact was applied for four hours at $14^{\circ} \mathrm{C}$.

During August/September each year these wines were sensorially evaluated by trained tasting panels. A ten-point-line-scorecard system was used to evaluate wine quality, colour, overall cultivar intensity, aroma, acid, tannins, hardness and fullness.

\section{Statistical analysis}

The data was subjected to an analysis of variance. Student's t least significant difference (LSD) values were calculated to facilitate comparison between treatment means. Means which differed at $p \leq 0.05$ were considered to be significantly different.

\section{RESULTS AND DISCUSSION}

\section{Trial at Nietvoorbij}

All three alternative pruning methods significantly reduced labour cost for managing Cabernet Sauvignon compared to hand pruning (Table 1). Not only was labour input for pruning reduced, but also for canopy management and harvest. Minimal and no pruning required significantly less labour than hand and mechanical pruning. It is imperative that mechanical harvesting is used when any one of the alternative pruning methods are employed as it is extremely labour intensive and costly to harvest these systems by hand.

More sunburn as well as berry shatter occurred when any one of the alternative pruning methods were used (Table 2). With the hand pruned control plots, the shoots were vertically positioned as part of the canopy management programme, therefore, the bunches were better protected against direct sunlight. On the other hand, the open hanging shoots of the minimal and no pruning plots, exposed the grapes more to direct sunlight and in abnormally hot seasons (data not shown), this caused sunburn-damage. The higher percentage berry shatter that occurred with the alternative prun-

\section{TABLE 1}

Labour inputs for different pruning methods for Cabernet Sauvignon grafted onto Richter 99 at Nietvoorbij (2000 - 2004$).$

\begin{tabular}{|c|c|c|c|c|}
\hline \multirow{2}{*}{ Parameter } & \multicolumn{4}{|c|}{ Labour (man hours/ha) } \\
\hline & Hand pruning & Mechanical pruning** & Minimal pruning** & No pruning** \\
\hline Pruning & $91.4 \mathrm{a}^{*}$ & $20.4 \mathrm{~b}$ & $0.7 \mathrm{c}$ & $0 \mathrm{c}$ \\
\hline Canopy management & $123.2 \mathrm{a}$ & $10.2 \mathrm{~b}$ & $11.4 \mathrm{~b}$ & $6.4 \mathrm{c}$ \\
\hline Harvesting & $97.5 \mathrm{a}$ & $1.5 \mathrm{~b}$ & $1.5 \mathrm{~b}$ & $1.5 \mathrm{~b}$ \\
\hline Total labour input & $312.1 \mathrm{a}$ & $32.1 \mathrm{~b}$ & $13.6 \mathrm{c}$ & $7.9 \mathrm{c}$ \\
\hline
\end{tabular}

* Figures followed by the same letter in the row do not differ significantly at $p \leq 0.05$.

** Grapes from the alternative pruning plots were machine harvested. 
ing, may be the result of a higher cluster exposure to wind during flowering time (data not shown). No pruning induced less compact bunches than any of the other pruning methods (Table 2).

The alternative pruning methods decreased shoot length significantly compared to the hand pruned control (Table 3 ) and amongst them, the vines pruned mechanically had the longest shoots. The internode length was affected similarly (Table 3). This can be related to the fact that the capacity of alternatively pruned vines was expressed in significantly more shoots per vine than in the case of the hand pruned control (Table 3). As expected, the highest cane mass was obtained from the hand pruned control vines.

Bud counts made during one data year (data not shown), showed that 24, 72, 191 and 227 buds per vine were left with hand, mechanical, minimal and no pruning respectively. This resulted in $\%$ budburst of $108 \%, 60 \%, 49 \%$ and $47 \%$ respectively.
A significantly lower yield was obtained from the hand pruned control vines (Table 3). A clear seasonal interaction with treatments can be seen in Fig. 1A. In most years the hand pruned plots yielded less but at least it was relatively consistent from year to year, while the alternative pruning treatments varied much more. The 2003 season was extremely favourable for hiegh yields for alternatively pruned Cabernet Sauvignon. Over the five year trial period, this treatment accumulatively produced less grapes than the other treatments (Fig. 1B) and of the alternative methods; no pruning produced significantly more grapes.

Although the bunch mass was significantly reduced by alternative pruning, the increased number of bunches ensured that the yield per ha increased. The hand pruned control vines produced significantly larger berries than the other pruning treatments (Table 3).

\section{TABLE 2}

Effect of pruning method on the physical condition of Cabernet Sauvignon grapes at harvest at Nietvoorbij (2000 - 2004).

\begin{tabular}{lcccc}
\hline Parameter & Hand pruning & Mechanical pruning & Minimal pruning & No pruning \\
\hline Dry rot (\%) & $0 \mathrm{a} *$ & $0.2 \mathrm{a}$ & $0.2 \mathrm{a}$ & 0 \\
Sour rot (\%) & 0 & 0 & $0 \mathrm{a}$ & $0.3 \mathrm{a}$ \\
Bird damage (\%) & $0 \mathrm{a}$ & $0.2 \mathrm{a}$ & $9.7 \mathrm{a}$ & $0.6 \mathrm{a}$ \\
Sun burn (\%) & $2.2 \mathrm{c}$ & $6.6 \mathrm{~b} \mathrm{a}$ & $3.2 \mathrm{~b}$ \\
Berry shatter (\%) & $0.3 \mathrm{c}$ & $1.6 \mathrm{c}$ & $0.5 \mathrm{a}$ & $0.4 \mathrm{a}$ \\
Millerandage (\%) & $0.2 \mathrm{a}$ & $0.3 \mathrm{a}$ & Well filled & Loose \\
Bunch compactness & Well filled & Well filled & None & None \\
Diseases/pests & None & None & & \\
\hline
\end{tabular}

* Figures followed by the same letter in the row do not differ significantly at $p \leq 0.05$.

TABLE 3

Effect of pruning method on the viticulture performance of Cabernet Sauvignon at Nietvoorbij (2000 - 2004).

\begin{tabular}{|c|c|c|c|c|}
\hline Parameter & Hand pruning & Mechanical pruning & Minimal pruning & No pruning \\
\hline \multicolumn{5}{|c|}{ Viticultural performance } \\
\hline Average shoot length $(\mathrm{cm})$ & $99.9 \mathrm{a}^{*}$ & $70.9 \mathrm{~b}$ & $19.7 \mathrm{c}$ & $18.6 \mathrm{c}$ \\
\hline Number shoots/vine & $26 \mathrm{~d}$ & $43 \mathrm{c}$ & $93 \mathrm{~b}$ & $108 \mathrm{a}$ \\
\hline Average internode length $(\mathrm{cm})$ & $6.24 \mathrm{a}$ & $5.45 \mathrm{~b}$ & $3.28 \mathrm{c}$ & $3.10 \mathrm{c}$ \\
\hline Cane mass (t/ha) & $3.3 \mathrm{a}$ & $1.4 \mathrm{~b}$ & $\mathrm{~nm}$ & $\mathrm{~nm}$ \\
\hline Yield (t/ha) & $10.1 \mathrm{c}$ & $18.0 \mathrm{~b}$ & $16.4 \mathrm{~b}$ & $20.1 \mathrm{a}$ \\
\hline Number of bunches/vine & $33.8 \mathrm{~d}$ & $83.4 \mathrm{c}$ & $106.6 \mathrm{~b}$ & $140.9 \mathrm{a}$ \\
\hline Bunch mass (g) & $130.0 \mathrm{a}$ & $87.5 \mathrm{~b}$ & $64.6 \mathrm{c}$ & $61.3 \mathrm{c}$ \\
\hline Berry mass (g) & $1.54 \mathrm{a}$ & $1.42 \mathrm{~b}$ & $1.18 \mathrm{c}$ & $1.19 \mathrm{c}$ \\
\hline Berry volume (mL) & $1.44 \mathrm{a}$ & $1.40 \mathrm{a}$ & $1.14 \mathrm{~b}$ & $1.16 \mathrm{~b}$ \\
\hline \multicolumn{5}{|c|}{ Grape composition } \\
\hline Sugar concentration $\left({ }^{\circ} \mathrm{B}\right)$ & $24.0 \mathrm{a}$ & $24.0 \mathrm{a}$ & $22.9 \mathrm{~b}$ & $22.8 \mathrm{~b}$ \\
\hline Acid concentration $(\mathrm{g} / \mathrm{L})$ & $7.7 \mathrm{a}$ & $7.4 \mathrm{~b}$ & $7.4 \mathrm{~b}$ & $7.5 \mathrm{ab}$ \\
\hline $\mathrm{pH}$ & $3.66 \mathrm{a}$ & $3.32 \mathrm{~b}$ & $3.27 \mathrm{c}$ & $3.24 \mathrm{c}$ \\
\hline Sugar:acid ratio & $3.2 \mathrm{~b}$ & $3.3 \mathrm{a}$ & $3.1 \mathrm{~b}$ & $3.1 \mathrm{~b}$ \\
\hline \multicolumn{5}{|c|}{ Must composition (after skin contact) } \\
\hline Sugar concentration $\left({ }^{\circ} \mathrm{B}\right)$ & $24.2 \mathrm{a}$ & $24.6 \mathrm{a}$ & $23.4 \mathrm{~b}$ & $22.8 \mathrm{c}$ \\
\hline Acid concentration $(\mathrm{g} / \mathrm{L})$ & $6.9 \mathrm{a}$ & $6.1 \mathrm{~b}$ & $6.8 \mathrm{a}$ & $6.7 \mathrm{a}$ \\
\hline $\mathrm{pH}$ & $3.47 \mathrm{~b}$ & $3.58 \mathrm{a}$ & $3.47 \mathrm{~b}$ & $3.45 \mathrm{~b}$ \\
\hline Sugar:acid ratio & $3.6 \mathrm{~b}$ & $3.9 \mathrm{a}$ & $3.5 \mathrm{~b}$ & $3.6 \mathrm{~b}$ \\
\hline
\end{tabular}

* Figures followed by the same letter in the row do not differ significantly at $p \leq 0.05$.

$\mathrm{nm}=$ not measured 


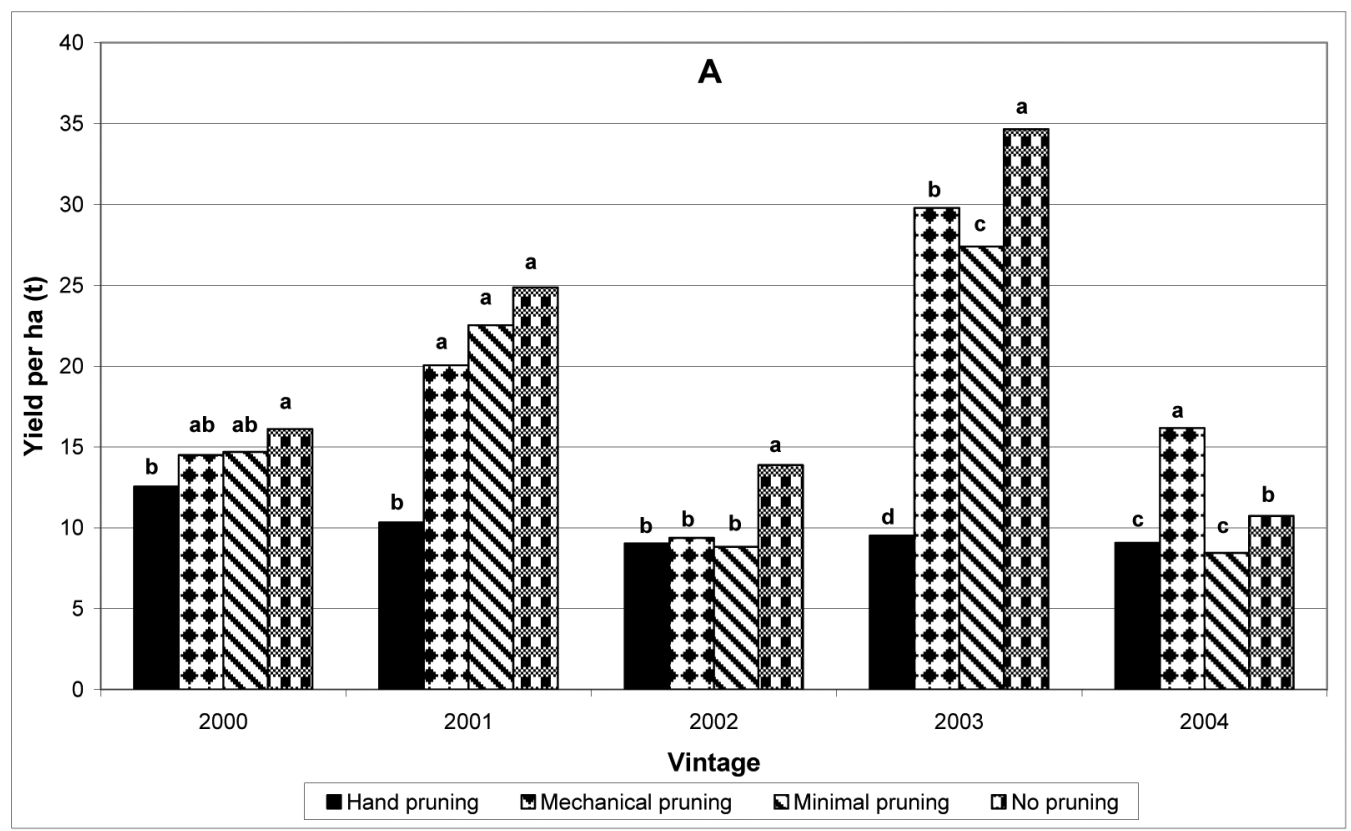

Vertical bars followed by the same letter in the same vintage do not differ significantly at $p \leq 0.05$.

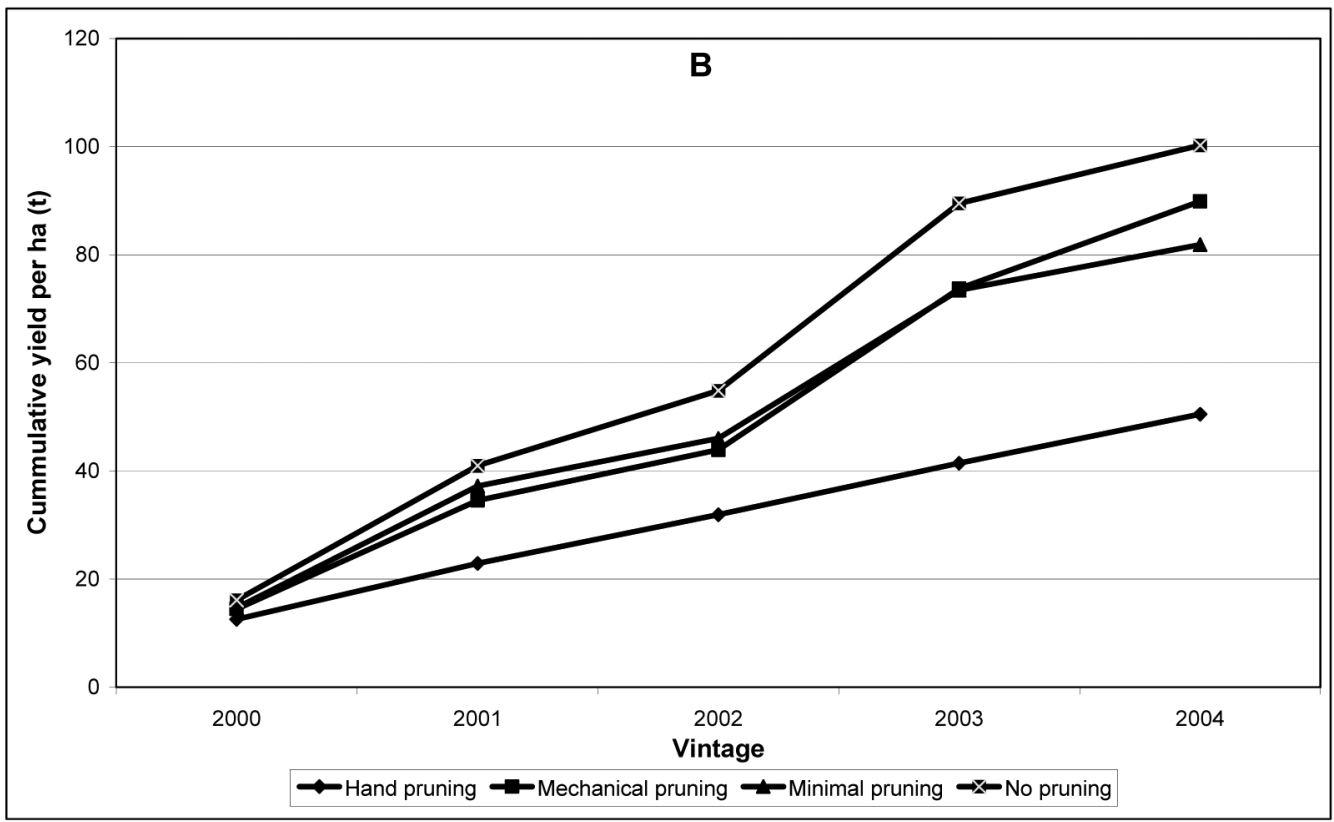

FIGURE 1

The effect of alternative pruning methods on the yearly (A) and cumulative (B) yield per ha of Cabernet Sauvignon at Nietvoorbij (2000 - 2004).

Vines that were hand and mechanically pruned, produced grapes with a higher sugar concentration than minimally and nonpruned vines (Table 3 ). The grapes from the alternative pruning treatments had a lower $\mathrm{pH}$ than those from hand pruned vines and this tendency was carried forward into the wine (Table 4) even though it was not true for the juice after crushing (Table 3). This higher $\mathrm{pH}$ in grapes and wine from hand pruned vines is ascribed to higher shade levels in the bunch zone of these VSP trained plots (data not shown). In general, the alternative pruning methods induced better colour in the skins and wines (Table 4) and this is ascribed to better sunlight penetration into the bunch zone of these vines (data not shown). These results are in accordance with those reported by Clingeleffer (1988 \& 1993).
The aroma profiles and overall quality of the wines are indicated in Figs. 2 \& 3. Vintage played an important role and over years succeeded in blanketing the treatment effects in the case of 6-month-old wines (Fig. 2). In spite of this, the wines from the hand pruned vines consistently showed the most pronounced vegetative character. This is expected due to a higher canopy density (more shade) in the bunch zone. This tendency also held true in most vintages for the 18-month-old wines (Fig. 3). These results are in accordance with those of numerous other researchers who found a better expression of fruitiness in wines from alternatively prunes vines. In spite of this, an evaluation of overall quality showed that the trained panel of judges had a preference for wines from the hand pruned vines (Table 5). 


\section{Trial at Elsenburg}

Hand pruning, together with the necessary canopy management as well as harvest, require 273.6 man hours/ha compared to 43.8 and 14.4 man hours/ha for mechanical and minimal pruning respectively (Table 6). This saving in man hours was true for all the varieties and there is a clear economic advantage to use anyone of the alternative pruning methods. During this trial, time studies showed that it is not viable to harvest any of the alternatively pruned plots by hand (data not shown). A mechanical harvester is a prerequisite when these methods are used.
The number of canes per vine of the three white varieties were increased with the alternative pruning methods, but the average cane length was reduced (Table 7). This reduction could, in part, be ascribed to a reduction in internode length. The other cause of the reduction in cane length with the alternative pruning methods could be found in the vigour reducing effect of an increased crop load. In this regard, interesting differences occurred between varieties. Although the cane length of Chardonnay was not affected by mechanical pruning, minimal pruning significantly decreased the vigour of this variety. The explanation for this can be found in the yield/ha which was increased by $248 \%$ with minimal

\section{TABLE 4}

Effect of pruning method on the oenological performance of Cabernet Sauvignon at Nietvoorbij (1998 - 2005).

\begin{tabular}{|c|c|c|c|c|}
\hline Parameter & Hand pruning & Mechanical pruning & Minimal pruning & No pruning \\
\hline Alcohol concentration ( $\mathrm{vol} \%$ ) & $14.6 b^{*}$ & $15.1 \mathrm{a}$ & $14.9 \mathrm{a}$ & $13.8 \mathrm{c}$ \\
\hline Extract (mg/L) & $33.3 \mathrm{a}$ & $33.6 \mathrm{a}$ & $31.4 \mathrm{~b}$ & $31.2 \mathrm{~b}$ \\
\hline Volatile acid (mg/L) & $0.22 \mathrm{a}$ & $0.25 \mathrm{a}$ & $0.24 \mathrm{a}$ & $0.22 \mathrm{a}$ \\
\hline Sugar concentration $(\mathrm{g} / \mathrm{L})$ & $1.7 \mathrm{~b}$ & $2.0 \mathrm{a}$ & $1.7 \mathrm{~b}$ & $1.7 \mathrm{~b}$ \\
\hline Acid concentration $(\mathrm{g} / \mathrm{L})$ & $6.5 \mathrm{c}$ & $7.0 \mathrm{~b}$ & $7.0 \mathrm{~b}$ & $7.3 \mathrm{a}$ \\
\hline $\mathrm{pH}$ & $3.86 \mathrm{a}$ & $3.74 \mathrm{~b}$ & $3.61 \mathrm{~b}$ & $3.58 \mathrm{~b}$ \\
\hline Skin colour (420nm) & $0.227 \mathrm{c}$ & $0.267 \mathrm{~b}$ & $0.292 \mathrm{a}$ & $0.280 \mathrm{a}$ \\
\hline Skin colour (520nm) & $1.000 \mathrm{c}$ & $1.235 \mathrm{~b}$ & $1.358 \mathrm{ab}$ & $1.328 \mathrm{a}$ \\
\hline Wine colour (420nm) & $0.562 \mathrm{~b}$ & $0.701 \mathrm{a}$ & $0.583 \mathrm{c}$ & $0.626 \mathrm{~b}$ \\
\hline Wine colour (520nm) & $0.858 \mathrm{~b}$ & $1.083 \mathrm{a}$ & $0.897 \mathrm{~b}$ & $0.999 \mathrm{ab}$ \\
\hline
\end{tabular}

* Figures followed by the same letter in the row do not differ significantly at $p \leq 0.05$.

\section{TABLE 5}

Effect of pruning method on the wine quality of 6 and 18 month old Cabernet Sauvignon wines at Nietvoorbij (2000 - 2004).

\begin{tabular}{|c|c|c|c|c|}
\hline Parameter & Hand pruning & Mechanical pruning & Minimal pruning & No pruning \\
\hline Overall wine quality after 6 months (\%) & $56.5 \mathrm{a}^{*}$ & $54.8 \mathrm{ab}$ & $52.1 \mathrm{~b}$ & $52.3 \mathrm{~b}$ \\
\hline Overall wine quality after 18 months (\%) & $61.0 \mathrm{a}$ & $61.0 \mathrm{a}$ & $48.3 \mathrm{~b}$ & $52.4 \mathrm{~b}$ \\
\hline Overall cultivar character after 6 months (\%) & $66.5 \mathrm{a}$ & $65.4 \mathrm{a}$ & $59.0 \mathrm{~b}$ & $58.1 \mathrm{~b}$ \\
\hline Overall cultivar character after 18 months (\%) & $67.4 \mathrm{a}$ & $64.5 \mathrm{ab}$ & $61.5 \mathrm{~b}$ & $61.0 \mathrm{~b}$ \\
\hline
\end{tabular}

* Figures followed by the same letter in the row do not differ significantly at $p \leq 0.05$.

\section{TABLE 6}

Labour inputs for different pruning methods for different varieties grafted onto Richter 99 at Elsenburg (2001 - 2004).

\begin{tabular}{|c|c|c|c|c|c|c|c|c|c|c|c|c|}
\hline \multirow[t]{3}{*}{ Variety } & \multicolumn{12}{|c|}{ Labour (man hours/ha) } \\
\hline & \multicolumn{4}{|c|}{ Hand pruning } & \multicolumn{4}{|c|}{ Mechanical pruning** } & \multicolumn{4}{|c|}{ Minimal pruning** } \\
\hline & Pruning & $\begin{array}{c}\text { Canopy } \\
\text { manage- } \\
\text { ment }\end{array}$ & Harvest & Total & Pruning & $\begin{array}{c}\text { Canopy } \\
\text { manage- } \\
\text { ment }\end{array}$ & Harvest & Total & Pruning & $\begin{array}{c}\text { Canopy } \\
\text { manage- } \\
\text { ment }\end{array}$ & Harvest & Total \\
\hline Chardonnay & $37.8 a^{*}$ & $111.4 \mathrm{a}$ & $74.7 \mathrm{a}$ & $223.9 \mathrm{a}$ & $27.9 \mathrm{~b}$ & $23.3 \mathrm{~b}$ & $1.4 \mathrm{~b}$ & $55.1 \mathrm{~b}$ & $0 \mathrm{c}$ & $12.4 \mathrm{c}$ & $1.5 \mathrm{~b}$ & 14.2 \\
\hline Chenin blanc & $88.4 \mathrm{a}$ & $162.7 \mathrm{a}$ & $107.0 \mathrm{a}$ & 358.1 a & $19.7 \mathrm{~b}$ & $14.0 \mathrm{~b}$ & $1.4 \mathrm{~b}$ & $34.1 \mathrm{~b}$ & $0 \mathrm{c}$ & $16.0 \mathrm{~b}$ & $1.5 \mathrm{~b}$ & $17.5 \mathrm{~b}$ \\
\hline Sauvigon blanc & $71.4 \mathrm{a}$ & $125.1 \mathrm{a}$ & $94.3 \mathrm{a}$ & 2908 a & $44.1 \mathrm{~b}$ & $17.2 \mathrm{~b}$ & $1.4 \mathrm{~b}$ & $62.7 \mathrm{~b}$ & $0 \mathrm{c}$ & $15.0 \mathrm{~b}$ & $1.5 \mathrm{~b}$ & $16.5 \mathrm{~b}$ \\
\hline Pinotage & $36.5 \mathrm{a}$ & $130.3 \mathrm{a}$ & $136.2 \mathrm{a}$ & 3030 a & $23.8 \mathrm{a}$ & $10.0 \mathrm{~b}$ & $1.4 \mathrm{~b}$ & $35.2 \mathrm{~b}$ & $0 \mathrm{c}$ & $12.5 \mathrm{~b}$ & $1.5 \mathrm{~b}$ & $14.0 \mathrm{~b}$ \\
\hline Merlot & $28.0 \mathrm{a}$ & $74.3 \mathrm{a}$ & $78.1 \mathrm{a}$ & 180.4 a & $12.4 \mathrm{~b}$ & $6.4 \mathrm{~b}$ & $1.4 \mathrm{~b}$ & $20.2 \mathrm{~b}$ & $0 \mathrm{c}$ & $8.8 \mathrm{~b}$ & $1.5 \mathrm{~b}$ & $1.3 \mathrm{~b}$ \\
\hline Cabernet Sauvignon & $82.7 \mathrm{a}$ & $134.3 \mathrm{a}$ & $63.3 \mathrm{a}$ & $285.3 \mathrm{a}$ & $41.3 \mathrm{~b}$ & $12.8 \mathrm{~b}$ & $1.4 \mathrm{~b}$ & $55.5 \mathrm{~b}$ & $0 \mathrm{c}$ & $12.4 \mathrm{~b}$ & $1.5 \mathrm{~b}$ & $13.9 \mathrm{c}$ \\
\hline Average & $54.5 \mathrm{a}$ & $128.9 \mathrm{a}$ & $92.3 \mathrm{a}$ & $273.6 \mathrm{a}$ & $28.2 \mathrm{~b}$ & $14.0 \mathrm{~b}$ & $1.4 \mathrm{~b}$ & $43.8 \mathrm{~b}$ & $0 \mathrm{c}$ & $12.9 \mathrm{~b}$ & $1.5 \mathrm{~b}$ & $14.4 \mathrm{c}$ \\
\hline
\end{tabular}

* Figures for the same action in the row, followed by the same letter, do not differ significantly at $p \leq 0.05$.

** Grapes from the alternative pruning plots were machine harvested. 


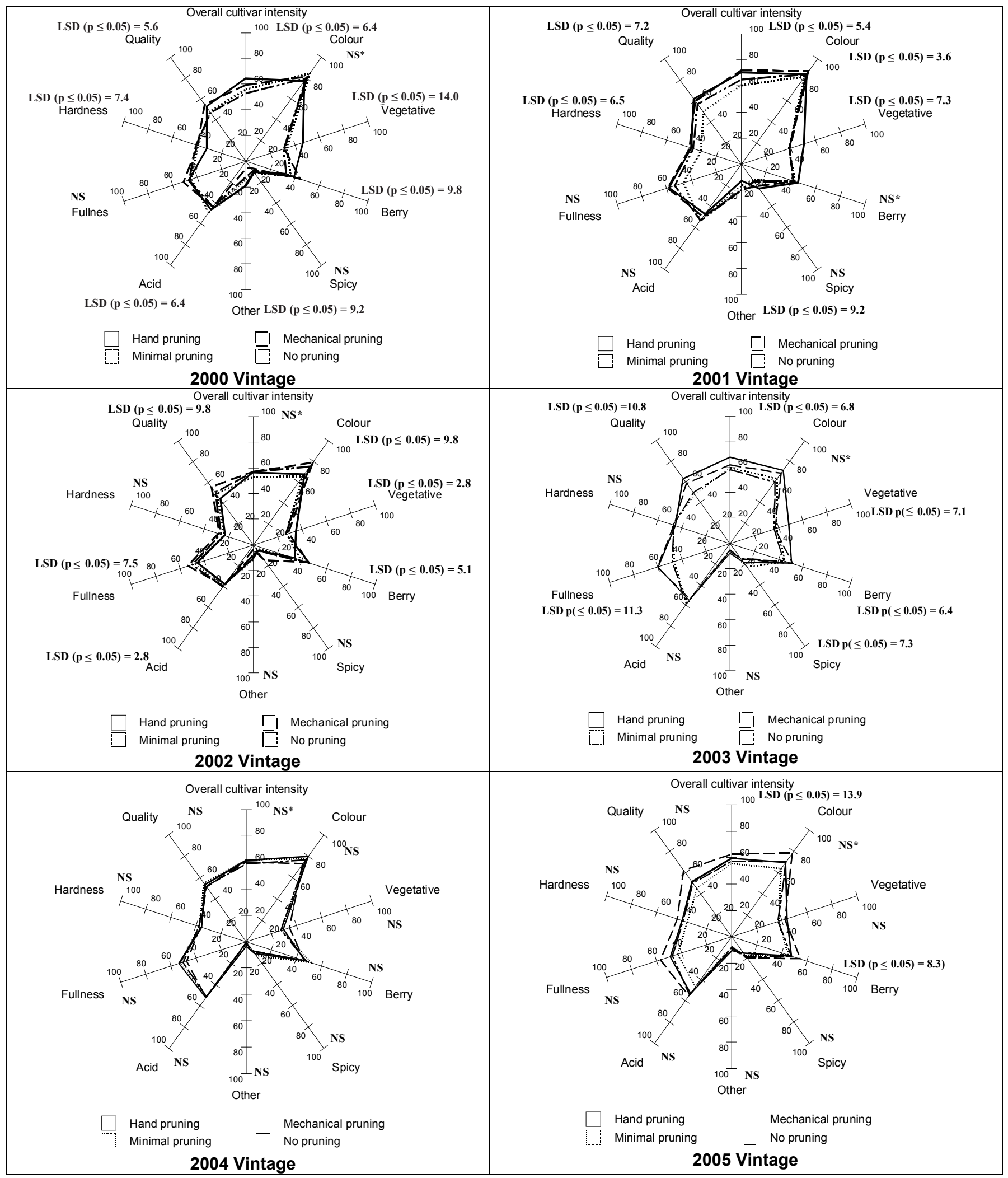

Statistical differences indicated in the figures $(p \leq 0.05)$.

${ }^{*} \mathrm{NS}=$ non significant.

FIGURE 2

Effect of alternative pruning methods on the aroma profiles and wine quality of 6-month-old Cabernet Sauvignon at Nietvoorbij (2000 - 2005). 


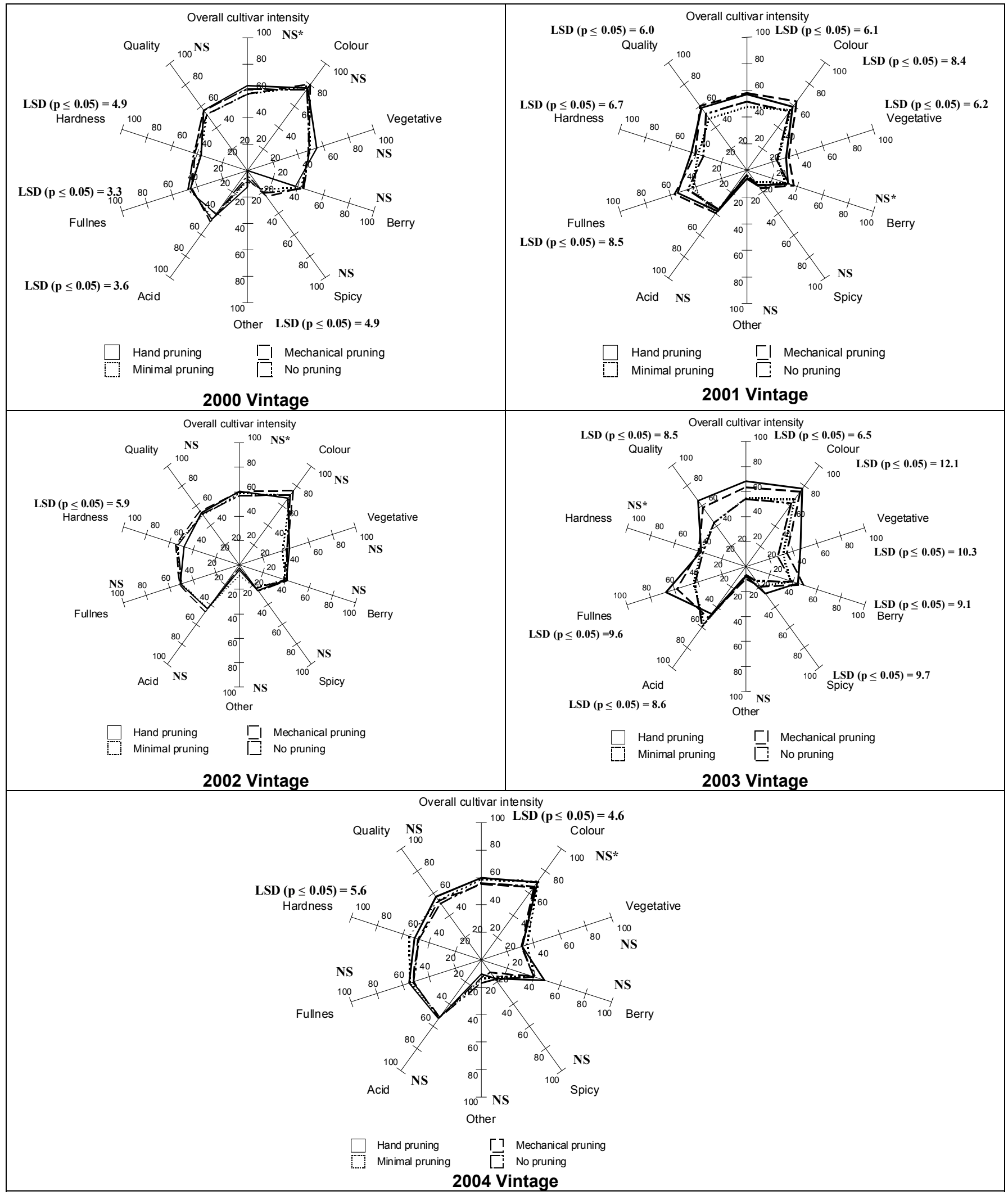

Statistical differences indicated in the figures $(p \leq 0.05)$.

${ }^{*} \mathrm{NS}=$ non significant

FIGURE 3

Effect of pruning methods on the aroma profiles and wine quality of 18-month-old Cabernet Sauvignon at Nietvoorbij (2000 - 2005). 
pruning (Table 9). In the cases of both Chenin blanc and Sauvignon blanc, the vigour was significantly reduced by both the alternative pruning methods. This reduction was partly caused by the huge crop induced by mechanical (76\% and 97\% respectively) as well as minimal pruning (155\% and $230 \%$ respectively) (Table 9 ). Field observations showed that, especially in the case of Chenin blanc, shoot growth came to a rather abrupt arrest compared to both Chardonnay and Sauvignon blanc. This has important im- plications for fertilization and irrigation when alternative pruning methods are applied.

The alternative pruning methods significantly increased the yield in the case of all varieties (Tables $7 \& 8$ ) while bunch mass, berry mass and berry volume decreased. The decrease in berry size and volume can be ascribed to a significant increase in the number of bunches per vine (Tables $7 \& 8$ ) as well as an increase in the fruit mass: leaf surface area relationship (data not shown). Mini-

TABLE 7

Effect of pruning method on the viticulture performance of the three different white varieties at Elsenburg (2001 - 2004).

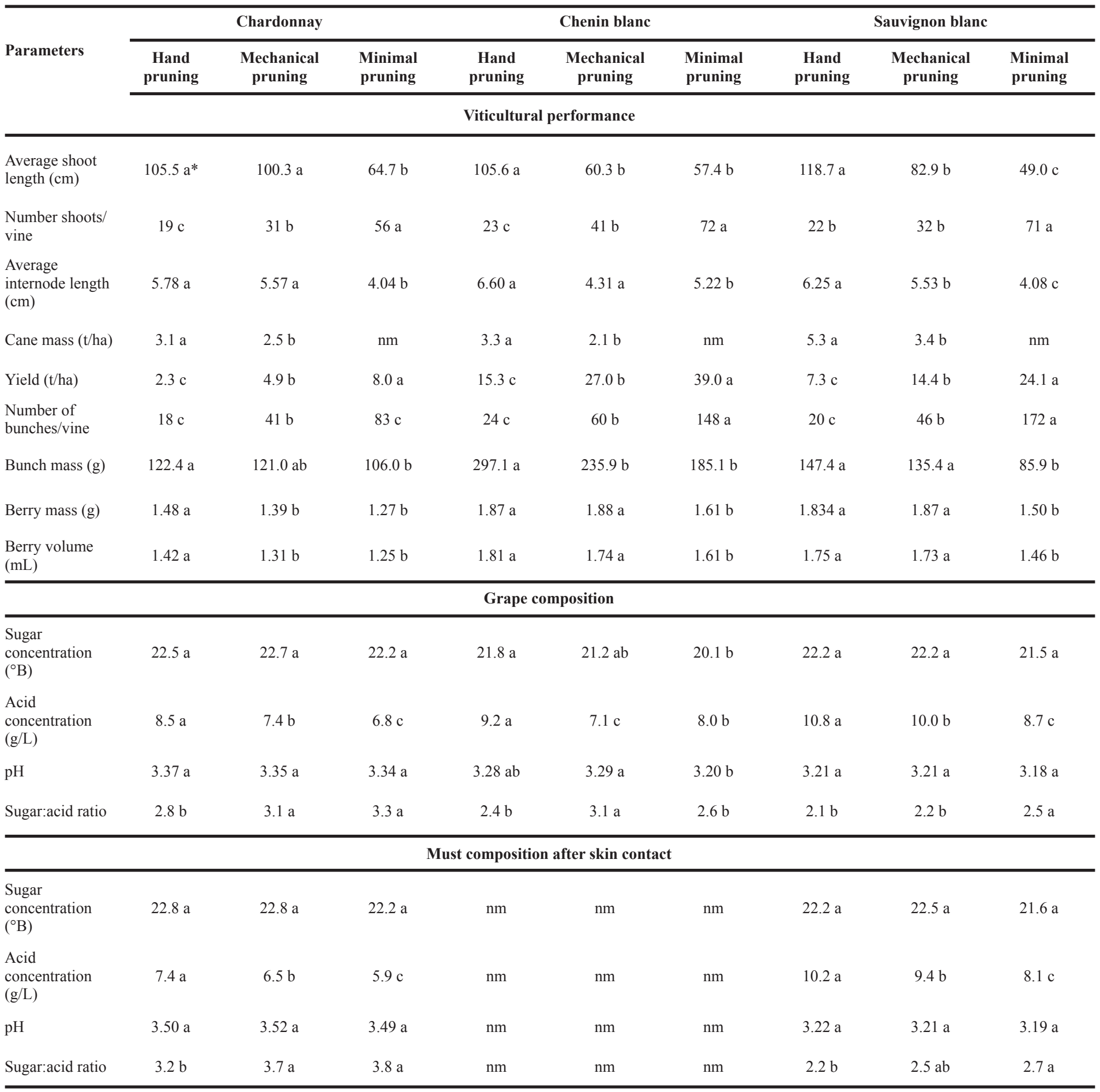

*Figures for different treatments per variety, followed by the same letter, do not differ significantly at $p \leq 0.05$. $\mathrm{nm}=$ not measured 
mal pruning increased the number of bunches for Chardonnay, Chenin blanc and Sauvignon blanc by $361 \%, 517 \%$ and $760 \%$ respectively (Table 9). Of the three white varieties, Sauvignon blanc showed the biggest decrease in berry mass and volume, bunch mass, cane length and internode length, while it showed the biggest increase in number of bunches per vine, number of canes per vine and the second largest increase in yield. After only four years of data this raises a question as to the adaptability of this variety to alternative pruning methods. Taking the same parameters into account, Chardonnay seems to be better adaptable to alternative pruning. Further research into this aspect is necessary.

In the case of the red varieties, Cabernet Sauvignon reacted to mechanical pruning in a similar way than Chardonnay. Minimal pruning significantly increased the number of canes per vine with all three red varieties, but the average cane length was significant- ly decreased mainly because of a reduction in internode length (Table 8).

Similarly to the white varieties, minimal pruning induced the biggest changes in all measured parameters in the red varieties compared to hand pruning (Table 9). Merlot showed the biggest increase in number of shoots for both alternative pruning methods and at the same time it showed the biggest decrease in cane length. Field observations showed that the shoot growth of this variety came to a rather abrupt arrest during the middle of the growing season even though the crop stress was not as high as in the case of the other two varieties. Although Cabernet Sauvignon showed the biggest decrease in internode length, it maintained shoot growth over a longer period. This, together with the fact that it showed the biggest increase in bunch number and yield, points to the adaptability of this variety to alternative pruning methods.

TABLE 8

Effect of pruning method on the viticulture performance of the three different red varieties at Elsenburg (2001 - 2004).

\begin{tabular}{|c|c|c|c|c|c|c|c|c|c|}
\hline \multirow[b]{2}{*}{ Parameters } & \multicolumn{3}{|c|}{ Pinotage } & \multicolumn{3}{|c|}{ Merlot } & \multicolumn{3}{|c|}{ Cabernet sauvignon } \\
\hline & $\begin{array}{c}\text { Hand } \\
\text { pruning }\end{array}$ & $\begin{array}{l}\text { Mechanical } \\
\text { pruning }\end{array}$ & $\begin{array}{l}\text { Minimal } \\
\text { pruning }\end{array}$ & $\begin{array}{c}\text { Hand } \\
\text { pruning }\end{array}$ & $\begin{array}{l}\text { Mechanical } \\
\text { pruning }\end{array}$ & $\begin{array}{c}\text { Minimal } \\
\text { pruning }\end{array}$ & $\begin{array}{c}\text { Hand } \\
\text { pruning }\end{array}$ & $\begin{array}{l}\text { Mechanical } \\
\text { pruning }\end{array}$ & $\begin{array}{c}\text { Minimal } \\
\text { pruning }\end{array}$ \\
\hline \multicolumn{10}{|c|}{ Viticultural performance } \\
\hline $\begin{array}{l}\text { Average shoot } \\
\text { length }(\mathrm{cm})\end{array}$ & $86.6 \mathrm{a}^{*}$ & $71.4 \mathrm{~b}$ & $52.2 \mathrm{c}$ & $77.1 \mathrm{a}$ & $60.0 \mathrm{~b}$ & $36.2 \mathrm{c}$ & $114.5 \mathrm{a}$ & $106.3 \mathrm{a}$ & $57.0 \mathrm{~b}$ \\
\hline $\begin{array}{l}\text { Number shoots/ } \\
\text { vine }\end{array}$ & $24 \mathrm{~b}$ & $24 \mathrm{~b}$ & $52 \mathrm{a}$ & $18 \mathrm{~b}$ & $21 \mathrm{~b}$ & $45 \mathrm{a}$ & $26 \mathrm{~b}$ & $28 \mathrm{~b}$ & $63 \mathrm{~b}$ \\
\hline $\begin{array}{l}\text { Average } \\
\text { internode length } \\
(\mathrm{cm})\end{array}$ & $5.41 \mathrm{a}$ & $5.10 \mathrm{ab}$ & $4.02 \mathrm{c}$ & $5.51 \mathrm{a}$ & $5.00 \mathrm{a}$ & $4.53 \mathrm{~b}$ & $6.74 \mathrm{a}$ & $5.32 \mathrm{a}$ & $4.07 \mathrm{~b}$ \\
\hline Cane mass (t/ha) & $2.9 \mathrm{a}$ & $1.8 \mathrm{~b}$ & $\mathrm{~nm}$ & $2.0 \mathrm{a}$ & $0.9 \mathrm{~b}$ & $\mathrm{~nm}$ & $6.3 \mathrm{a}$ & $4.5 \mathrm{~b}$ & $\mathrm{~nm}$ \\
\hline Yield (t/ha) & $8.3 \mathrm{~b}$ & $13.8 \mathrm{a}$ & $14.2 \mathrm{a}$ & $9.8 \mathrm{~b}$ & $11.7 \mathrm{a}$ & $10.6 \mathrm{ab}$ & $7.4 \mathrm{~b}$ & $11.9 \mathrm{ab}$ & $15.9 \mathrm{a}$ \\
\hline $\begin{array}{l}\text { Number of } \\
\text { bunches/vine }\end{array}$ & $38 \mathrm{c}$ & $58 \mathrm{~b}$ & $78 \mathrm{a}$ & $26 \mathrm{c}$ & $45 \mathrm{~b}$ & $61 \mathrm{a}$ & $23 \mathrm{c}$ & $61 \mathrm{~b}$ & $98 \mathrm{a}$ \\
\hline Bunch mass (g) & $111.2 \mathrm{ab}$ & $118.8 \mathrm{a}$ & $104.6 \mathrm{~b}$ & $161.2 \mathrm{a}$ & $126.1 \mathrm{~b}$ & $109.4 \mathrm{~b}$ & $105.9 \mathrm{a}$ & $88.7 \mathrm{~b}$ & $74.5 \mathrm{c}$ \\
\hline Berry mass (g) & $1.67 \mathrm{a}$ & $1.54 \mathrm{ab}$ & $1.38 \mathrm{~b}$ & $1.49 \mathrm{a}$ & $1.43 \mathrm{a}$ & $1.25 \mathrm{~b}$ & $1.40 \mathrm{a}$ & $1.33 \mathrm{a}$ & $1.23 \mathrm{a}$ \\
\hline $\begin{array}{l}\text { Berry volume } \\
(\mathrm{mL})\end{array}$ & $1.53 \mathrm{a}$ & $1.48 \mathrm{a}$ & $1.30 \mathrm{~b}$ & $1.39 \mathrm{a}$ & $1.35 \mathrm{a}$ & $1.19 \mathrm{~b}$ & $1.37 \mathrm{a}$ & $1.27 \mathrm{ab}$ & $1.17 \mathrm{~b}$ \\
\hline \multicolumn{10}{|c|}{ Grape composition } \\
\hline $\begin{array}{l}\text { Sugar } \\
\text { concentration } \\
\left({ }^{\circ} \mathrm{B}\right)\end{array}$ & $25.0 \mathrm{a}$ & $24.2 \mathrm{ab}$ & $23.3 \mathrm{~b}$ & $23.0 \mathrm{a}$ & $23.2 \mathrm{a}$ & $23.3 \mathrm{a}$ & $24.1 \mathrm{a}$ & $23.5 \mathrm{a}$ & $23.1 \mathrm{a}$ \\
\hline $\begin{array}{l}\text { Acid } \\
\text { concentration } \\
(\mathrm{g} / \mathrm{L})\end{array}$ & $8.6 \mathrm{a}$ & $7.2 \mathrm{~b}$ & $6.8 \mathrm{~b}$ & $6.3 \mathrm{a}$ & $5.8 \mathrm{a}$ & $5.8 \mathrm{a}$ & $8.5 \mathrm{a}$ & $7.6 \mathrm{~b}$ & $7.4 \mathrm{~b}$ \\
\hline $\mathrm{pH}$ & $3.37 \mathrm{~b}$ & $3.46 \mathrm{ab}$ & $3.57 \mathrm{a}$ & $3.32 \mathrm{~b}$ & $3.41 \mathrm{a}$ & $3.36 \mathrm{ab}$ & $3.45 \mathrm{a}$ & $3.47 \mathrm{a}$ & $3.36 \mathrm{~b}$ \\
\hline Sugar:acid ratio & $3.0 \mathrm{~b}$ & $3.6 \mathrm{a}$ & $3.8 \mathrm{a}$ & $3.6 \mathrm{~b}$ & $4.0 \mathrm{a}$ & $4.0 \mathrm{a}$ & $2.8 \mathrm{~b}$ & $3.2 \mathrm{a}$ & $3.2 \mathrm{a}$ \\
\hline
\end{tabular}

* Figures for different treatments per variety, followed by the same letter, do not differ significantly at $p \leq 0.05$. $\mathrm{nm}=$ not measured 


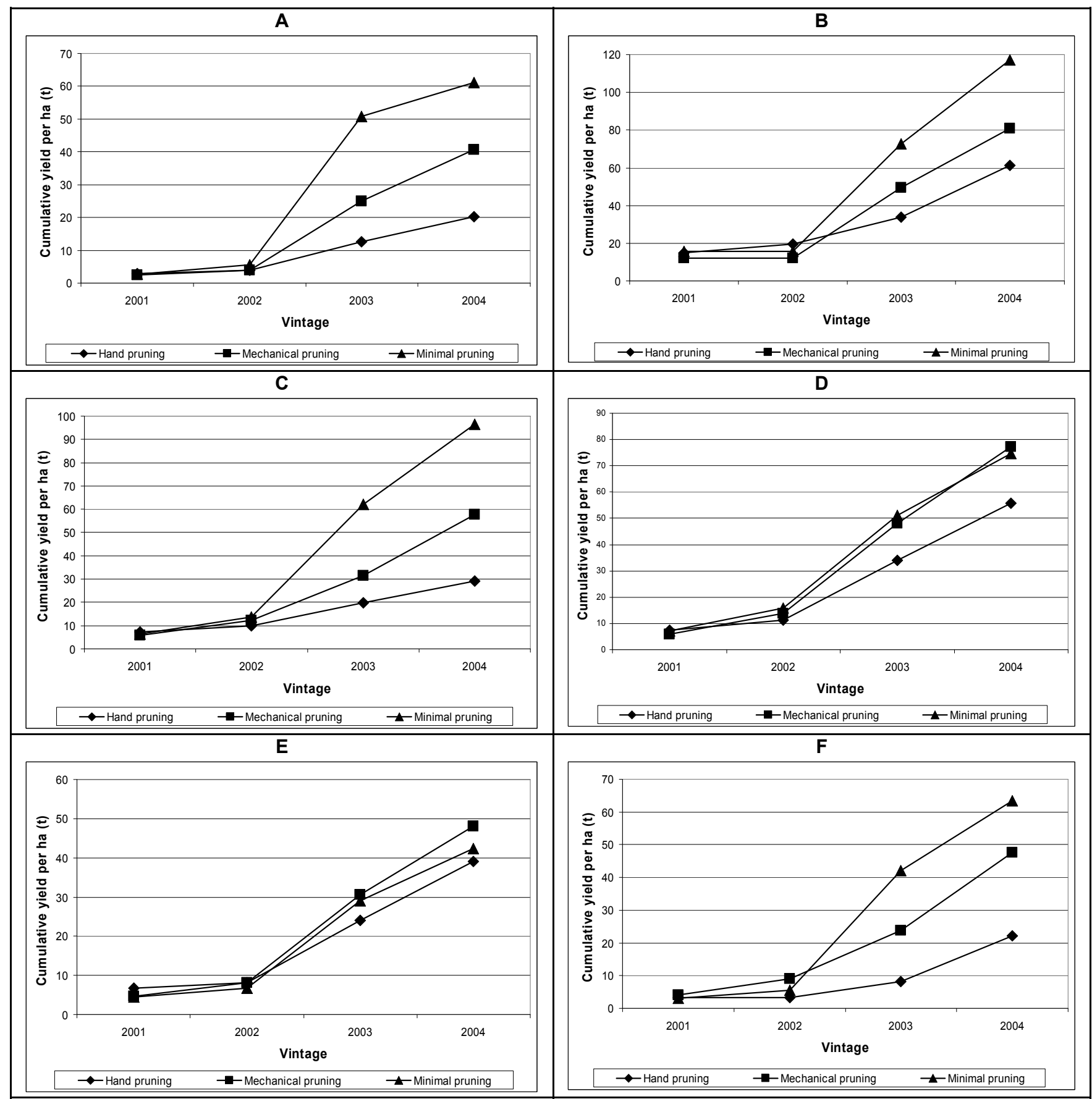

FIGURE 4

Effect of alternative pruning methods on the cumulative yield of six varieties at Elsenburg (2001 - 2004).

$\mathrm{A}=$ Chardonnay B $=$ Chenin blanc C $=$ Sauvignon blanc $; \mathrm{D}=$ Pinotage E = Merlot and $\mathrm{F}=$ Cabernet Sauvignon.

The bunch mass of Pinotage was least affected by alternative pruning and, combined with the relatively small change in the growth habit, this indicates that this variety also adapts well to alternative pruning methods. After only four data years it seems that Merlot is the least suitable for alternative pruning.

Except for Merlot and Pinotage the cumulative yield over four seasons for all varieties was highest for minimal pruning, pointing to an earlier break even point than for the other pruning methods (Fig. 4). The relative yield difference in the case of Merlot also was less expressed than for the other varieties, strengthening the observation that this variety may not adapt well to alternative pruning. The cumulative yield of minimally pruned Chenin blanc was the highest, while hand pruned Chardonnay and Cabernet Sauvignon were the lowest.

Although no clear pattern could be distinguished, important annual fluctuations in yield occurred (Fig. 5). As in the case of the trial at Nietvoorbij, 2003 season proved to be an excellent season for alternative pruning methods for all varieties at Elsenburg. The 


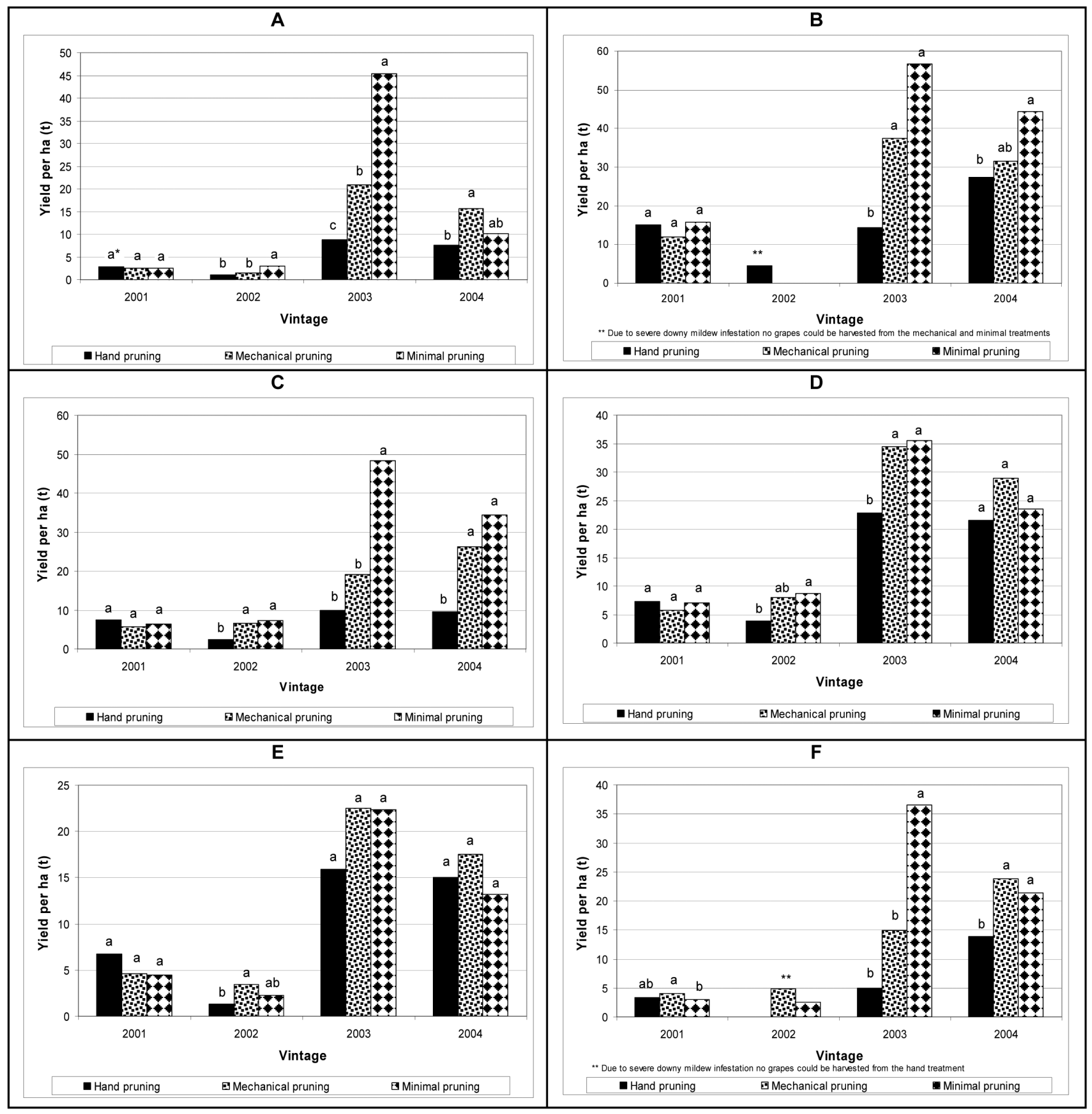

Vertical bars followed by the same letter in the same vintage do not differ significantly at $p \leq 0.05$.

\section{FIGURE 5}

Effect of alternative pruning methods on the annual yield of six varieties at Elsenburg (2001 - 2004).

$\mathrm{A}=$ Chardonnay; $\mathrm{B}=$ Chenin blanc; $\mathrm{C}=$ Sauvignon blanc; $\mathrm{D}=$ Pinotage; $\mathrm{E}=$ Merlot and $\mathrm{F}=$ Cabernet Sauvignon.

trail was approximately $7 \mathrm{~km}$ away and in the same climate region (Region III) than the one at Nietvoorbij. This tendency was not clearly shown for the Robertson (Region V) trial (see Fig. 13) and it points to the possibility that climate plays an important role in the performance of alternatively pruning methods. More data years are necessary to identify variety differences in this respect.

Different pruning methods had little effect on the oenological performance of the six varieties investigated (Tables $10 \& 11$ ). Minimally pruned Sauvignon blanc had lower extract, while me- chanically pruned Chenin blanc, mechanically and minimally pruned Sauvignon blanc showed a lower acid concentration (Table 10). Hand pruning induced less colour in the skins and wines of Cabernet Sauvignon, while the colour of Pinotage was negatively affected by alternative pruning methods (Table 11). Again, more research is necessary to establish if this pattern will continue over the longer term.

In three out of four years the citrus-like aroma of Chardonnay wines was enhanced by minimal pruning (Fig. 6), while the tree 
TABLE 9

Effect of pruning method on the percentage difference in relation to hand pruning for different varieties at Elsenburg (2001 - 2005).

\begin{tabular}{|c|c|c|c|c|c|c|c|c|c|c|c|c|}
\hline \multirow{2}{*}{ Parameters } & \multicolumn{2}{|c|}{ Chardonnay } & \multicolumn{2}{|c|}{ Chenin blanc } & \multicolumn{2}{|c|}{ Sauvignon blanc } & \multicolumn{2}{|c|}{ Pinotage } & \multicolumn{2}{|c|}{ Merlot } & \multicolumn{2}{|c|}{ Cabernet Sauvignon } \\
\hline & Mechanical & Minimal & Mechanical & Minimal & Mechanical & Minimal & Mechanical & Minimal & Mechanical & Minimal & Mechanical & Minimal \\
\hline $\begin{array}{l}\text { Average shoot } \\
\text { length }(\%)\end{array}$ & $-4.9 \mathrm{a}$ & $-38.7 b$ & $-42.7 \mathrm{a}$ & $-45.7 \mathrm{a}$ & $-30.1 \mathrm{a}$ & $-58.7 b$ & $-18.0 \mathrm{~b}$ & $-40.0 \mathrm{a}$ & $-22.0 \mathrm{a}$ & $-53.0 \mathrm{~b}$ & $-7.0 \mathrm{a}$ & $-50.0 \mathrm{~b}$ \\
\hline $\begin{array}{l}\text { Number } \\
\text { shoots/vine } \\
(\%)\end{array}$ & $63.0 \mathrm{~b}$ & $194.7 \mathrm{a}$ & $78.3 \mathrm{~b}$ & $213.0 \mathrm{a}$ & $45.5 \mathrm{~b}$ & $222.7 \mathrm{a}$ & $0.0 \mathrm{~b}$ & $116.0 \mathrm{a}$ & $17.0 \mathrm{~b}$ & $167.0 \mathrm{a}$ & $8.0 \mathrm{~b}$ & $142.0 \mathrm{a}$ \\
\hline $\begin{array}{l}\text { Average } \\
\text { internode } \\
\text { length }(\%)\end{array}$ & $-3.6 \mathrm{a}$ & $-30.1 b$ & $-34.7 b$ & $-20.9 \mathrm{a}$ & $-11.5 \mathrm{a}$ & $-34.7 b$ & $-6.0 \mathrm{a}$ & $-26 b$ & $-9.0 \mathrm{a}$ & $-18.0 \mathrm{~b}$ & $-21.0 \mathrm{a}$ & $-40.0 \mathrm{~b}$ \\
\hline $\begin{array}{l}\text { Cane mass } \\
(\%)\end{array}$ & $-19.4 \mathrm{a}$ & $\mathrm{nm}$ & $-36.4 \mathrm{a}$ & $\mathrm{nm}$ & $-35.8 \mathrm{a}$ & $\mathrm{nm}$ & $-38.0 \mathrm{a}$ & $\mathrm{nm}$ & $-55.0 \mathrm{a}$ & $\mathrm{nm}$ & $-29.0 \mathrm{a}$ & $\mathrm{nm}$ \\
\hline Yield (\%) & $113.0 \mathrm{~b}$ & $247.8 \mathrm{a}$ & $76.5 \mathrm{~b}$ & $155.0 \mathrm{a}$ & $97.0 \mathrm{~b}$ & $230.0 \mathrm{a}$ & $66.0 \mathrm{a}$ & $71.0 \mathrm{a}$ & $19.0 \mathrm{a}$ & $8.0 \mathrm{~b}$ & $61.0 \mathrm{~b}$ & $115.0 \mathrm{a}$ \\
\hline $\begin{array}{l}\text { Number of } \\
\text { bunches/vine } \\
(\%)\end{array}$ & $128.0 \mathrm{~b}$ & $361.0 \mathrm{a}$ & $150.0 \mathrm{~b}$ & $517.0 \mathrm{a}$ & $130.0 \mathrm{~b}$ & $760.0 \mathrm{a}$ & $53.0 \mathrm{~b}$ & $105.0 \mathrm{a}$ & $73.0 \mathrm{~b}$ & $135.0 \mathrm{a}$ & $165.0 \mathrm{~b}$ & $326.0 \mathrm{a}$ \\
\hline $\begin{array}{l}\text { Bunch mass } \\
(\%)\end{array}$ & $-1.1 \mathrm{a}$ & $-13.4 b$ & $-20.6 \mathrm{a}$ & $-38.0 b$ & $-9.0 \mathrm{a}$ & $-42.0 \mathrm{~b}$ & $-7.0 \mathrm{a}$ & $-6.0 \mathrm{~b}$ & $-22.0 \mathrm{a}$ & $-32.0 \mathrm{~b}$ & $-16.0 \mathrm{a}$ & $-30.0 b$ \\
\hline $\begin{array}{l}\text { Berry mass } \\
(\%)\end{array}$ & $-9.0 \mathrm{~b}$ & $-14.0 \mathrm{a}$ & $0.6 \mathrm{a}$ & $-14.0 \mathrm{~b}$ & $-2.0 \mathrm{a}$ & $-18.0 \mathrm{~b}$ & $-7.0 \mathrm{a}$ & $-18.0 \mathrm{~b}$ & $-4.0 \mathrm{a}$ & $-16.0 \mathrm{~b}$ & $-4.0 \mathrm{a}$ & $-12.0 b$ \\
\hline $\begin{array}{l}\text { Berry volume } \\
(\%)\end{array}$ & $-8.0 \mathrm{~b}$ & $-12.0 \mathrm{a}$ & $-4.0 \mathrm{a}$ & $-11.0 b$ & $-1.4 \mathrm{a}$ & $-17.0 \mathrm{~b}$ & $-4.0 \mathrm{a}$ & $-16.0 b$ & $-3.0 \mathrm{a}$ & $-15.0 \mathrm{~b}$ & $-8.0 \mathrm{a}$ & $-15.0 b$ \\
\hline
\end{tabular}

* Figures for the same variety and parameters in the row, followed by the same letter, do not differ significantly at $p \leq 0.05$.

** Not measured.

TABLE 10

Effect of pruning method on the oenological performance of the three different white varieties at Elsenburg (2001 - 2004).

\begin{tabular}{|c|c|c|c|c|c|c|c|c|c|}
\hline \multirow{2}{*}{ Parameters } & \multicolumn{3}{|c|}{ Chardonnay } & \multicolumn{3}{|c|}{ Chenin blanc } & \multicolumn{3}{|c|}{ Sauvignon blanc } \\
\hline & $\begin{array}{c}\text { Hand } \\
\text { pruning }\end{array}$ & $\begin{array}{c}\text { Mechanical } \\
\text { pruning }\end{array}$ & $\begin{array}{c}\text { Minimal } \\
\text { pruning }\end{array}$ & $\begin{array}{c}\text { Hand } \\
\text { pruning }\end{array}$ & $\begin{array}{c}\text { Mechanical } \\
\text { pruning }\end{array}$ & $\begin{array}{l}\text { Minimal } \\
\text { pruning }\end{array}$ & $\begin{array}{c}\text { Hand } \\
\text { pruning }\end{array}$ & $\begin{array}{c}\text { Mechanical } \\
\text { pruning }\end{array}$ & $\begin{array}{r}\text { Minimal } \\
\text { pruning }\end{array}$ \\
\hline Alcohol concentration (vol \%) & $13.9 \mathrm{a}^{*}$ & $13.9 \mathrm{a}$ & $13.3 \mathrm{a}$ & $13.1 \mathrm{a}$ & $12.8 \mathrm{ab}$ & $12.1 \mathrm{~b}$ & $13.6 \mathrm{ab}$ & $14.1 \mathrm{a}$ & $13.1 \mathrm{~b}$ \\
\hline Extract $(\mathrm{mg} / \mathrm{L})$ & $23.9 \mathrm{a}$ & $23.3 \mathrm{a}$ & $21.2 \mathrm{a}$ & $21.1 \mathrm{a}$ & $20.2 \mathrm{a}$ & $20.5 \mathrm{a}$ & $22.7 \mathrm{a}$ & $21.5 \mathrm{~b}$ & $21.7 \mathrm{~b}$ \\
\hline Volatile acid (mg/L) & $0.27 \mathrm{a}$ & $0.21 \mathrm{~b}$ & $0.20 \mathrm{~b}$ & $0.28 \mathrm{a}$ & $0.24 \mathrm{a}$ & $0.23 \mathrm{a}$ & $0.30 \mathrm{a}$ & $0.29 \mathrm{a}$ & $0.29 \mathrm{a}$ \\
\hline Free $\mathrm{SO}_{2}(\mathrm{~g} / \mathrm{L})$ & $28 \mathrm{a}$ & $27 \mathrm{a}$ & $28 \mathrm{a}$ & $27 \mathrm{a}$ & $27 \mathrm{a}$ & $28 \mathrm{a}$ & $33 \mathrm{a}$ & $29 \mathrm{~b}$ & $29 \mathrm{~b}$ \\
\hline Total $\mathrm{SO}_{2}(\mathrm{~g} / \mathrm{L})$ & $107 \mathrm{a}$ & $101 \mathrm{a}$ & 98 a & $88 \mathrm{a}$ & $90 \mathrm{a}$ & $88 \mathrm{a}$ & $95 \mathrm{a}$ & $95 \mathrm{a}$ & $102 \mathrm{a}$ \\
\hline Sugar concentration $(\mathrm{g} / \mathrm{L})$ & $3.4 \mathrm{a}$ & $2.9 \mathrm{a}$ & $2.4 \mathrm{a}$ & $2.4 \mathrm{a}$ & $2.5 \mathrm{a}$ & $2.9 \mathrm{a}$ & $2.1 \mathrm{a}$ & $2.3 \mathrm{a}$ & $2.2 \mathrm{a}$ \\
\hline Acid concentration $(\mathrm{g} / \mathrm{L})$ & $5.4 \mathrm{a}$ & $5.4 \mathrm{a}$ & $5.1 \mathrm{a}$ & $7.1 \mathrm{a}$ & $5.8 \mathrm{~b}$ & $6.6 \mathrm{a}$ & $6.9 \mathrm{a}$ & $6.0 \mathrm{~b}$ & $6.3 \mathrm{~b}$ \\
\hline $\mathrm{pH}$ & $3.62 \mathrm{a}$ & $3.61 \mathrm{a}$ & $3.47 \mathrm{~b}$ & $3.35 \mathrm{a}$ & $3.38 \mathrm{a}$ & $3.24 \mathrm{~b}$ & $3.24 \mathrm{ab}$ & $3.27 \mathrm{a}$ & $3.23 \mathrm{~b}$ \\
\hline
\end{tabular}

* Figures for different treatments per variety, followed by the same letter, do not differ significantly at $p \leq 0.05$.

fruit aroma benefited form mechanical pruning for two of the four vintages. This is ascribed to better fruit exposure brought about by alternative pruning methods (data not shown).

In one out of four years, the colour of Chenin blanc wines was improved by mechanical pruning (Fig. 7). During the same vintage, this pruning method decreased the acid concentration. During one year, minimal pruning decreased the overall quality of Chenin blanc wines. Chenin blanc wine did not benefit from alternative pruning.
The vegetative character of Sauvignon blanc wines was enhanced by hand pruning in two of the four vintages, probably because of less fruit exposure (Fig. 8), while it improved the acid concentration of one year only.

Hand pruning decreased the colour of Pinotage wines in two of the four vintages, while it decreased the vegetative aroma and overall quality twice (Fig. 9). There is a tendency that the colour is enhanced by mechanical pruning. These colour differences may be ascribed to differences in fruit exposure and berry size. 




Statistical differences indicated in the figures $(p \leq 0.05)$.

${ }^{*} \mathrm{NS}=$ non significant.

** Downy mildew caused severe damage in 2002 and wine could not be made from all the treatments and replicates thus no statistical analyses was applied.

FIGURE 6

Effect of pruning methods on the aroma profiles and wine quality of Chardonnay wines of four different vintages at Elsenburg (2001 - 2004). 


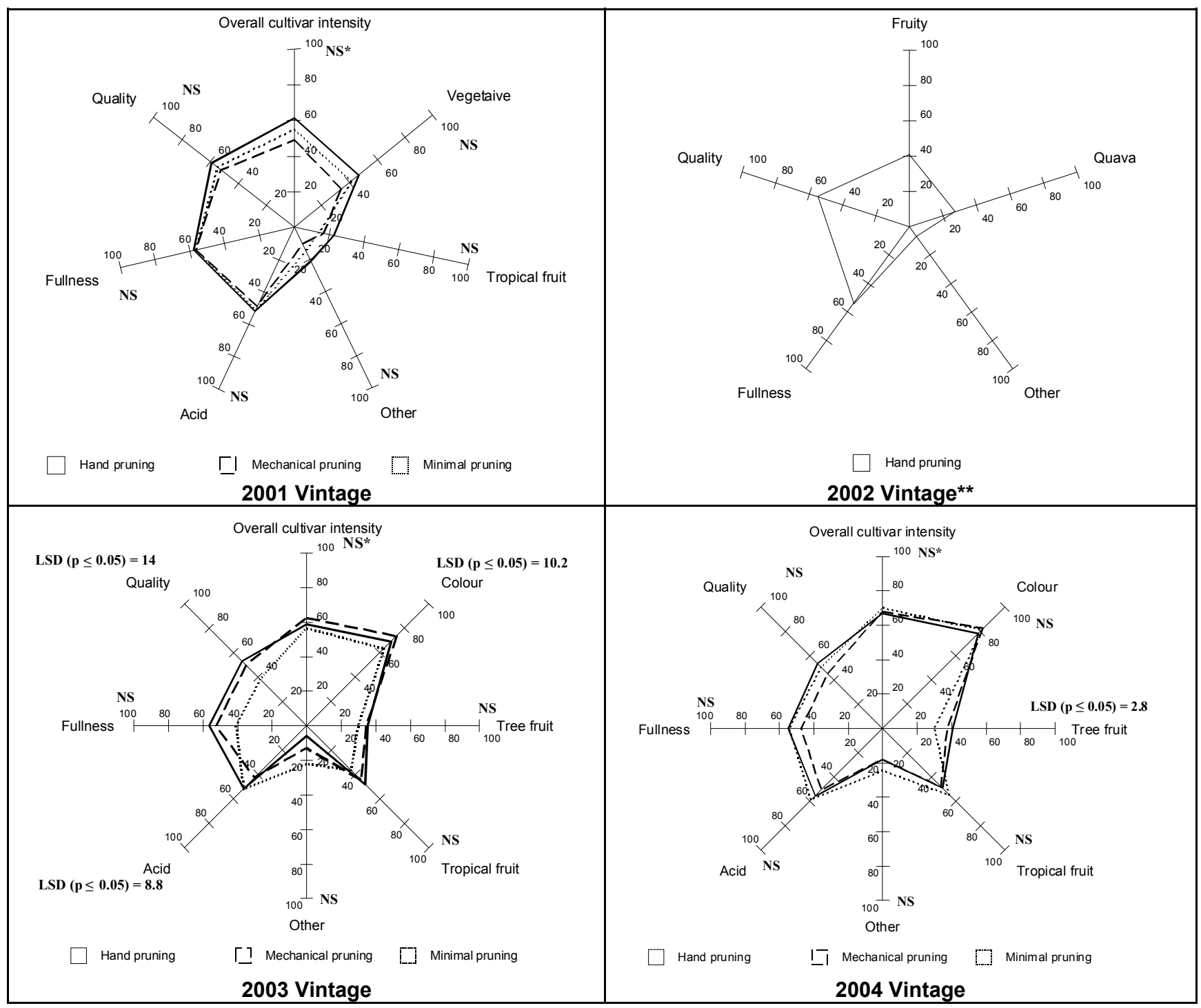

Statistical differences indicated in the figures $(p \leq 0.05)$.

${ }^{*} \mathrm{NS}=$ non significant.

** Downy mildew caused severe damage in 2002 and wine could not be made from all the treatments and replicates thus no statistical analyses was applied.

FIGURE 7

Effect of pruning methods on the aroma profiles and wine quality of Chenin blanc wines of four different vintages at Elsenburg (2001 - 2004).

No clear pattern is obvious form the aroma and quality profiles of Merlot wines, except that minimal pruning was responsible for wine colour reduction in three of the four vintages (Fig. 10) although the reduction was not significant. This cannot be explained because no skin colour differences occurred (see Table 11).

In three of the four vintages, alternative pruning enhanced the colour of Cabernet Sauvignon wine compared to hand pruning (Fig. 11). This was expected due to the improvement of the skin colour obtained in the grapes (see Table 11). In spite of this, minimal pruning produced the worst overall quality Cabernet wine in two of the three seasons. There is a tendency for wines form the hand pruned plots to be more vegetative in character and this is probably due to the bunches not being as well exposed to sunlight as in the case of the alternatively pruned plots. This probably contributed to the judges finding a higher overall cultivar intensity in the wines from the hand pruned plots.

\section{Trial at Robertson}

The same labour saving advantages obtained by alternative pruning methods in the trials at Nietvoorbij and Elsenburg, were realised in the trial at Robertson (Table 12). Hand pruning (including canopy management and harvesting) required 193.8 man hours/ ha, while 46.6 and 22.0 man hours/ha were used for mechanical and minimal pruning respectively. The man hours used for canopy management with the alternative pruning methods were for removing shoots on the trunks as well as mechanical trimming of shoots to open the work row. In the case of minimal pruning summer trimming of the shoots $30 \mathrm{~cm}$ above ground level is also included under canopy management. It is again necessary to state that mechanical harvesting is a prerequisite when anyone of the alternative pruning methods are used.

The average cane length was significantly decreased by alternative pruning with minimal pruning producing the shortest in- 


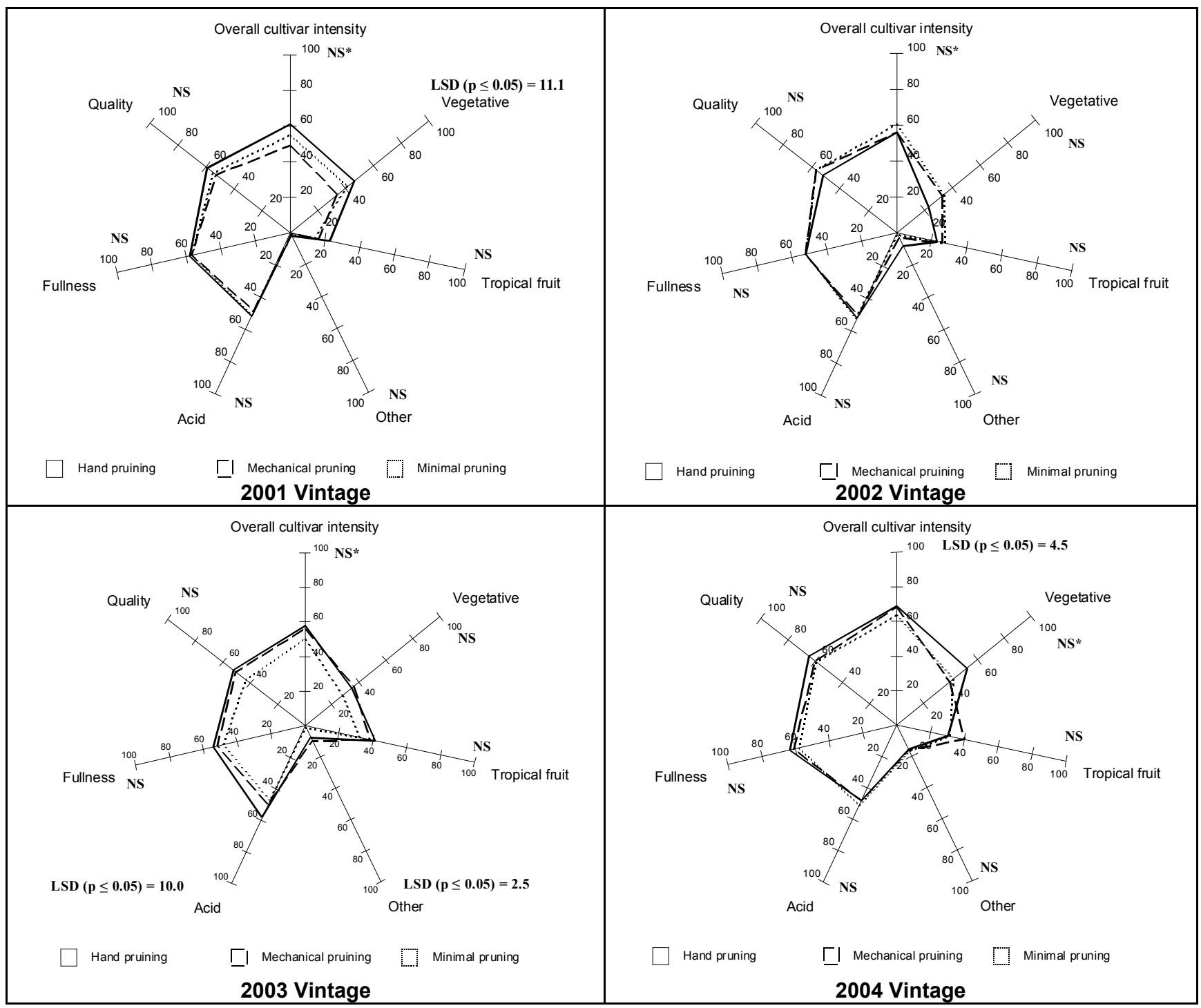

Statistical differences indicated in the figures $(p \leq 0.05) . \quad \quad{ }^{*} \mathrm{NS}=$ non significant.

FIGURE 8

Effect of pruning methods on the aroma profiles and wine quality of Sauvignon blanc wines of four different vintages at Elsenburg (2001 - 2004). 


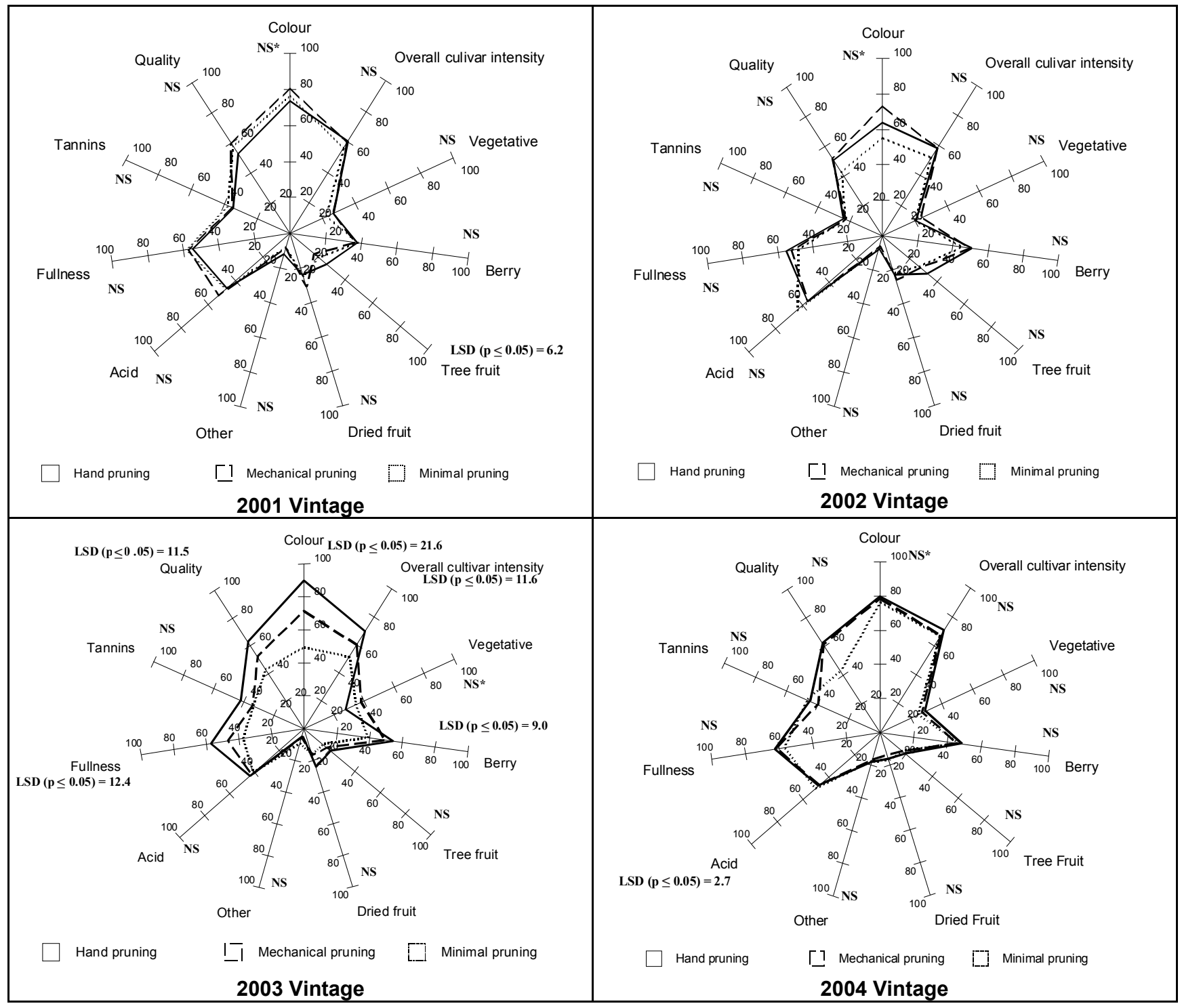

Statistical differences indicated in the figures $(p \leq 0.05)$.

${ }^{*} \mathrm{NS}=$ non significant

FIGURE 9

Effect of pruning methods on the aroma profiles and wine quality of Pinotage wines of four different vintages at Elsenburg (2001 - 2004). 


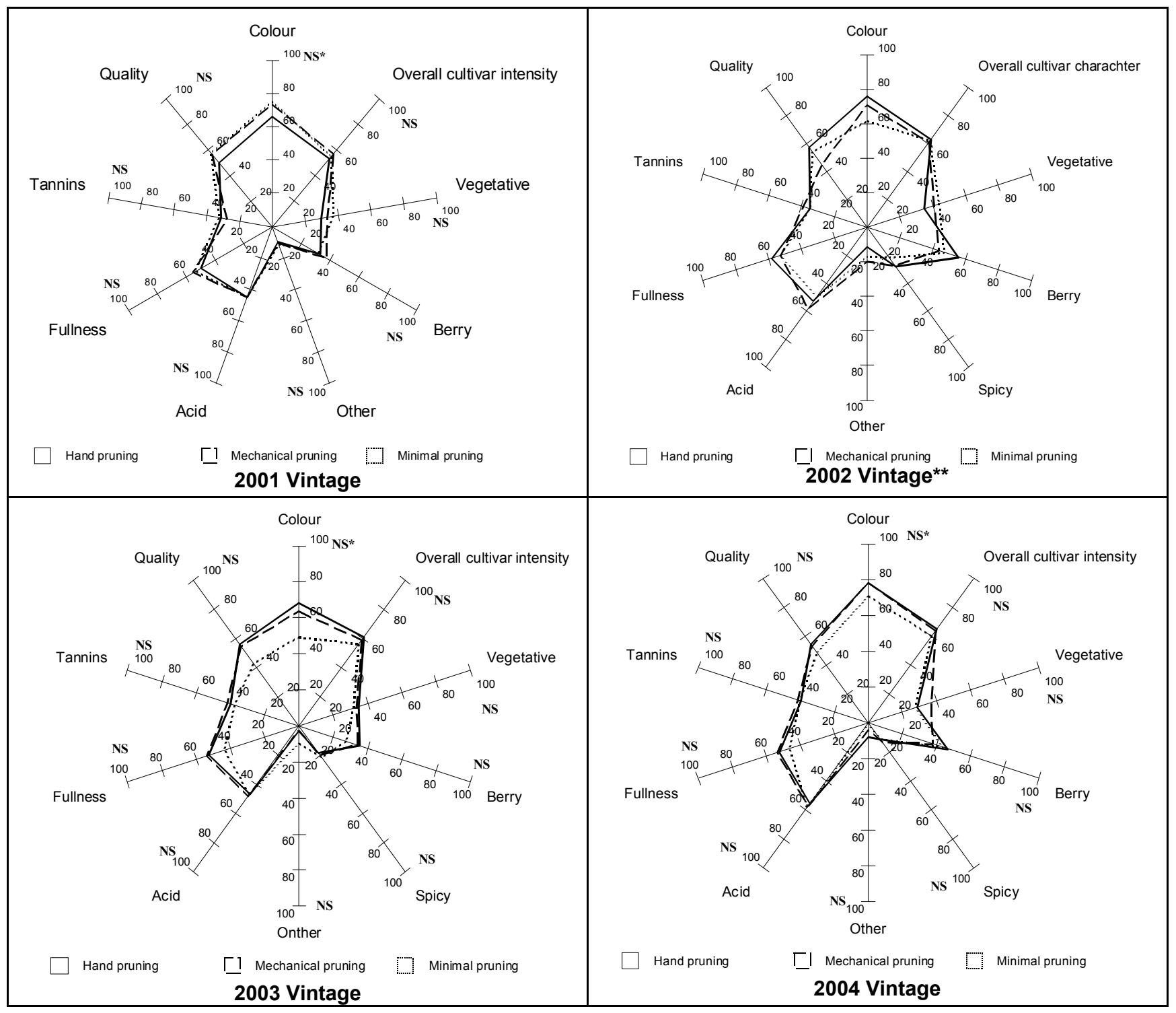

Statistical differences indicated in the figures $(p \leq 0.05)$.

${ }^{*} \mathrm{NS}=$ non significant

** Downy mildew caused severe damage in 2002 and wine could not be made from all the treatments and replicates thus no statistical analyses was applied.

FIGURE 10

Effect of pruning methods on the aroma profiles and wine quality of Merlot wines of four different vintages at Elsenburg (2001 - 2004). 


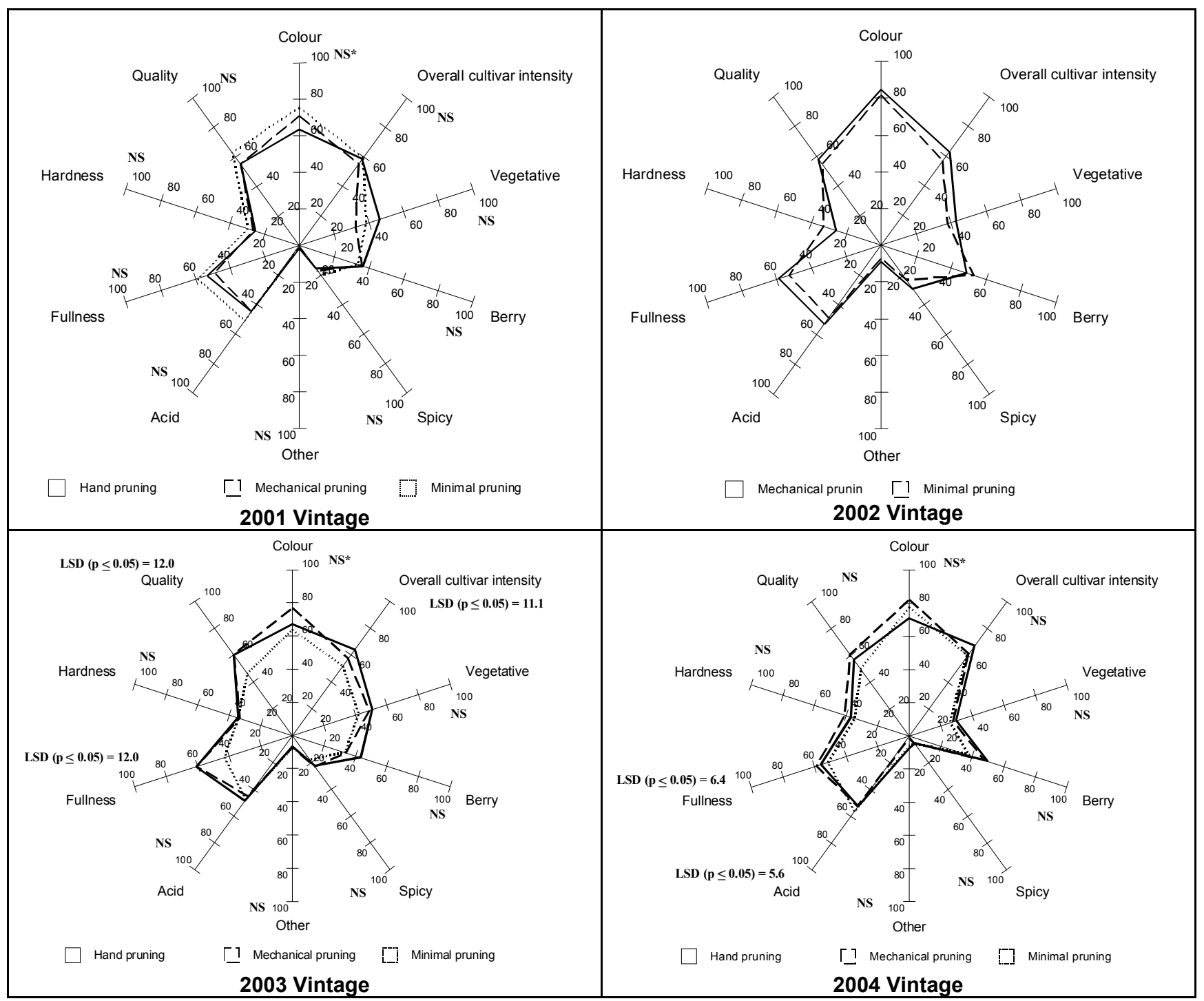

Statistical differences indicated in the figures $(p \leq 0.05)$.

${ }^{*} \mathrm{NS}=$ non significant.

** Downy mildew caused severe damage in 2002 and wine could not be made from all the treatments and replicates thus no statistical analyses was applied.

FIGURE 11

Effect of pruning methods on the aroma profiles and wine quality of Cabernet Sauvignon wines of four different vintages at Elsenburg (2001 - 2004). 
TABLE 11

Effect of pruning method on the oenological performance of the three different red varieties at Elsenburg (2001 - 2004).

\begin{tabular}{|c|c|c|c|c|c|c|c|c|c|}
\hline \multirow[b]{2}{*}{ Parameters } & \multicolumn{3}{|c|}{ Pinotage } & \multicolumn{3}{|c|}{ Merlot } & \multicolumn{3}{|c|}{ Cabernet sauvignon } \\
\hline & $\begin{array}{c}\text { Hand } \\
\text { pruning }\end{array}$ & $\begin{array}{c}\text { Mechanical } \\
\text { pruning }\end{array}$ & $\begin{array}{l}\text { Minimal } \\
\text { pruning }\end{array}$ & $\begin{array}{c}\text { Hand } \\
\text { pruning }\end{array}$ & $\begin{array}{c}\text { Mechanical } \\
\text { pruning }\end{array}$ & $\begin{array}{c}\text { Minimal } \\
\text { pruning }\end{array}$ & $\begin{array}{c}\text { Hand } \\
\text { pruning }\end{array}$ & $\begin{array}{c}\text { Mechanical } \\
\text { pruning }\end{array}$ & $\begin{array}{c}\text { Minimal } \\
\text { pruning }\end{array}$ \\
\hline Alcohol concentration (vol \%) & $15.0 \mathrm{a}^{*}$ & $14.5 \mathrm{a}$ & $14.1 \mathrm{a}$ & $14.5 \mathrm{a}$ & $14.4 \mathrm{a}$ & $14.6 \mathrm{a}$ & $14.2 \mathrm{a}$ & $14.6 \mathrm{a}$ & $14.0 \mathrm{a}$ \\
\hline Extract $(\mathrm{mg} / \mathrm{L})$ & $33.8 \mathrm{a}$ & $32.6 \mathrm{a}$ & $31.9 \mathrm{a}$ & $30.4 \mathrm{a}$ & $29.6 \mathrm{a}$ & $29.8 \mathrm{a}$ & $34.7 \mathrm{a}$ & $35.1 \mathrm{a}$ & $31.6 \mathrm{~b}$ \\
\hline Volatile acid (mg/L) & $0.44 \mathrm{a}$ & $0.37 \mathrm{~b}$ & $0.38 \mathrm{~b}$ & $0.25 \mathrm{~b}$ & $0.26 \mathrm{~b}$ & $0.35 \mathrm{a}$ & $0.22 \mathrm{a}$ & $0.23 \mathrm{a}$ & $0.20 \mathrm{~b}$ \\
\hline Free $\mathrm{SO}_{2}(\mathrm{~g} / \mathrm{L})$ & $55 \mathrm{a}$ & $56 \mathrm{a}$ & $54 \mathrm{a}$ & $42 \mathrm{a}$ & $41 \mathrm{a}$ & $41 \mathrm{a}$ & $45 \mathrm{a}$ & $42 \mathrm{~b}$ & $43 \mathrm{ab}$ \\
\hline Total $\mathrm{SO}_{2}(\mathrm{~g} / \mathrm{L})$ & $68 \mathrm{a}$ & $71 \mathrm{a}$ & $69 \mathrm{a}$ & $81 \mathrm{a}$ & $81 \mathrm{a}$ & $83 \mathrm{a}$ & $81 \mathrm{a}$ & $77 \mathrm{~b}$ & $78 \mathrm{ab}$ \\
\hline Sugar concentration $(\mathrm{g} / \mathrm{L})$ & $2.0 \mathrm{a}$ & $2.0 \mathrm{a}$ & $1.8 \mathrm{a}$ & $1.6 \mathrm{~b}$ & $1.7 \mathrm{ab}$ & $1.8 \mathrm{a}$ & $1.8 \mathrm{a}$ & $1.7 \mathrm{ab}$ & $1.6 \mathrm{~b}$ \\
\hline Acid concentration $(\mathrm{g} / \mathrm{L})$ & $6.8 \mathrm{a}$ & $6.0 \mathrm{~b}$ & $6.4 \mathrm{ab}$ & $6.1 \mathrm{a}$ & $6.3 \mathrm{a}$ & $6.3 \mathrm{a}$ & $6.2 \mathrm{a}$ & $6.8 \mathrm{a}$ & $6.9 \mathrm{a}$ \\
\hline $\mathrm{pH}$ & $3.82 \mathrm{a}$ & $3.86 \mathrm{a}$ & $3.81 \mathrm{a}$ & $3.62 \mathrm{a}$ & $3.60 \mathrm{a}$ & $3.54 \mathrm{a}$ & $3.93 \mathrm{a}$ & $3.88 \mathrm{a}$ & $3.68 \mathrm{~b}$ \\
\hline Skin colour (420nm) & $0.359 \mathrm{a}$ & $0.388 \mathrm{a}$ & $0.449 \mathrm{a}$ & $0.480 \mathrm{a}$ & $0.451 \mathrm{a}$ & $0.506 \mathrm{a}$ & $0.271 \mathrm{~b}$ & $0.339 \mathrm{a}$ & $0.355 \mathrm{a}$ \\
\hline Skin colour $(520 \mathrm{~nm})$ & $1.623 \mathrm{a}$ & $1.749 \mathrm{a}$ & $2.059 \mathrm{a}$ & $2.270 \mathrm{a}$ & $2.141 \mathrm{a}$ & $2.078 \mathrm{a}$ & $1.214 \mathrm{~b}$ & $1.603 \mathrm{a}$ & $1.717 \mathrm{a}$ \\
\hline Wine colour $(420 \mathrm{~nm})$ & $0.763 \mathrm{a}$ & $0.741 \mathrm{ab}$ & $0.604 \mathrm{~b}$ & $0.688 \mathrm{a}$ & $0.749 \mathrm{a}$ & $0.723 \mathrm{a}$ & $0.669 \mathrm{~b}$ & $0.915 \mathrm{a}$ & $0.740 \mathrm{~b}$ \\
\hline Wine colour $(520 \mathrm{~nm})$ & $1.263 \mathrm{a}$ & $1.120 \mathrm{ab}$ & $0.986 \mathrm{~b}$ & $1.134 \mathrm{a}$ & $1.202 \mathrm{a}$ & $1.185 \mathrm{a}$ & $0.885 \mathrm{~b}$ & $1.284 \mathrm{a}$ & $1.145 \mathrm{a}$ \\
\hline
\end{tabular}

* Figures for different treatments per variety, followed by the same letter, do not differ significantly at $p \leq 0.05$.

TABLE 12

Labour inputs for different pruning methods for different varieties grafted onto Richter 99 at Robertson (2001 - 2006).

\begin{tabular}{|c|c|c|c|c|c|c|c|c|c|c|c|c|}
\hline \multirow{3}{*}{ Variety } & \multicolumn{12}{|c|}{ Labour (man hours/ha) } \\
\hline & \multicolumn{4}{|c|}{ Hand pruning } & \multicolumn{4}{|c|}{ Mechanical pruning** } & \multicolumn{4}{|c|}{ Minimal pruning** } \\
\hline & Pruning & $\begin{array}{c}\text { Canopy } \\
\text { manage- } \\
\text { ment }\end{array}$ & Harvest & Total & Pruning & $\begin{array}{l}\text { Canopy } \\
\text { manage- } \\
\text { ment*** }\end{array}$ & Harvest & Total & Pruning & $\begin{array}{l}\text { Canopy } \\
\text { manage- } \\
\text { ment*** }\end{array}$ & Harvest & Total \\
\hline Chardonnay & $52.4 \mathrm{a}$ & $54.5 \mathrm{a}$ & $86.5 \mathrm{a}$ & $193.4 \mathrm{a}$ & $19.6 \mathrm{~b}$ & $18.9 \mathrm{~b}$ & $1.4 \mathrm{~b}$ & $39.9 \mathrm{~b}$ & $0 \mathrm{c}$ & $17.4 \mathrm{c}$ & $1.5 \mathrm{~b}$ & $18.9 \mathrm{c}$ \\
\hline Chenin blanc & $61.9 \mathrm{a}$ & $51.1 \mathrm{a}$ & $90.5 \mathrm{a}$ & $203.4 \mathrm{a}$ & $22.7 \mathrm{~b}$ & $21.9 \mathrm{~b}$ & $1.4 \mathrm{~b}$ & $46.0 \mathrm{~b}$ & $0 \mathrm{c}$ & $20.1 \mathrm{c}$ & $1.5 \mathrm{~b}$ & $21.5 \mathrm{c}$ \\
\hline Colombar & $57.3 \mathrm{a}$ & $34.0 \mathrm{a}$ & $76.8 \mathrm{a}$ & $168.1 \mathrm{a}$ & $22.2 \mathrm{~b}$ & $17.0 \mathrm{~b}$ & $1.4 \mathrm{~b}$ & $40.7 \mathrm{~b}$ & $0 \mathrm{c}$ & $16.2 \mathrm{~b}$ & $1.5 \mathrm{~b}$ & $17.7 \mathrm{c}$ \\
\hline Sauvignon blanc & $67.5 \mathrm{a}$ & $38.6 \mathrm{a}$ & $89.5 \mathrm{a}$ & $195.6 \mathrm{a}$ & $22.9 \mathrm{~b}$ & $31.5 \mathrm{~b}$ & $1.4 \mathrm{~b}$ & $55.8 \mathrm{~b}$ & $0 \mathrm{c}$ & $27.5 \mathrm{c}$ & $1.5 \mathrm{~b}$ & $29.0 \mathrm{c}$ \\
\hline Ruby Cabernet & $66.2 \mathrm{a}$ & $27.5 \mathrm{a}$ & $111.4 \mathrm{a}$ & $205.2 \mathrm{a}$ & $25.1 \mathrm{~b}$ & $17.4 \mathrm{~b}$ & $1.4 \mathrm{~b}$ & $43.9 \mathrm{~b}$ & $0 \mathrm{c}$ & $15.9 \mathrm{c}$ & $1.5 \mathrm{~b}$ & $17.4 \mathrm{c}$ \\
\hline Shiraz & $63.1 \mathrm{a}$ & $47.4 \mathrm{a}$ & $86.5 \mathrm{a}$ & $196.9 \mathrm{a}$ & $22.2 \mathrm{~b}$ & $29.4 \mathrm{~b}$ & $1.4 \mathrm{~b}$ & $53.0 \mathrm{~b}$ & $0 \mathrm{c}$ & $25.7 \mathrm{c}$ & $1.5 \mathrm{~b}$ & $27.2 \mathrm{c}$ \\
\hline Average & $61.4 \mathrm{a}$ & $41.9 \mathrm{a}$ & $90.2 \mathrm{a}$ & $193.8 \mathrm{a}$ & $22.5 \mathrm{a}$ & $19.9 \mathrm{~b}$ & $1.4 \mathrm{~b}$ & $46.6 \mathrm{~b}$ & $0 \mathrm{c}$ & $20.5 \mathrm{~b}$ & $1.5 \mathrm{~b}$ & $22.0 \mathrm{c}$ \\
\hline
\end{tabular}

* Figures for different treatments per variety, followed by the same letter, do not differ significantly at $p \leq 0.05$.

** Grapes from the alternative pruning plots were machine harvested.

*** Shoots on the vine trunks were removed. In the case of minimal pruning, shoots hanging down were trimmed to about $30 \mathrm{~cm}$ above soil level. Shoots of the mechanical and minimum pruned vines were also trimmed to open up the workrow.

ternodes (Table 13). On average, mechanical pruning reduced shoot length by $18 \%$ over all varieties, while minimal pruning was responsible for a $60 \%$ decrease (Table 14) compared to hand pruning. At the same time internode length was reduced by $10 \%$ and $40 \%$ respectively. In all cases the number of nodes per cane was significantly reduced by alternative pruning (data not shown) compared to hand pruning. The number of shoots per vine was significantly increased by the alternative pruning methods (Table 13 ), mechanical pruning increased it by $113 \%$ over hand pruning and minimal pruning by $400 \%$ (Table 14 ) respectively. Changes in cane length (decrease) and number of shoots (increase) brought about by mechanical pruning compared to hand pruning, resulted in no change in cane mass/ha in the case of Ruby Cabernet and Shiraz (Table 14) repsectively. The overall reduction in vigour caused by alternative pruning methods could partly be ascribed to the increases in yield (Table 13) compared to hand pruning. Minimal pruned vines only yielded more than mechanical pruned vines in the case of Chardonnay. Mechanical pruned vines performed the same or better than minimal pruned vines in the case of the other varieties. The possible yield reducing effect of a lower bunch mass in the case of the alternative pruning methods, was more than offset by a significant increase in bunch number (Table 13). The cumulative yield over the six vintages of this trail showed that Chardonnay and Shiraz profited by mechanical pruning, while Sauvignon blanc and Ruby Cabernet profited by minimal pruning (Fig. 12). In the case of Chenin blanc and Colombar no distinction can be made between mechanical and minimal pruning. It is, however, clear that these two alternative pruning methods had a yield advantage over hand pruning. No clear pattern emerged when seasonal yields were compared between varieties (Fig.13). 
Mechanical pruning increased the bunch number on average by $166 \%$ in all varieties, while minimal pruning was responsible for an increase or $360 \%$ (Table 14). The smaller bunches obtained with alternative pruning were not only caused by smaller berries (mass and volume), but also by a smaller physical size as shown by the bunch stem mass (Table 13).

Pruning methods had no clear effect on sugar concentration and in the case of Chardonnay, Sauvignon blanc and Ruby Cabernet, the acid concentration in the grapes was reduced (Table 13) compared to hand pruning. The effect of pruning method on must $\mathrm{pH}$ was not clear and it differed between varieties. More research is necessary to determine the effect of the alternative pruning methods on grape composition.

No clear trend in the effect of alternative pruning methods on the wine composition of the different varieties could be found except for wine colour where these methods improved the colour of Ruby Cabernet and Shiraz wines (Table 15). This may be derived from the better skin colour (possible better skin: juice relationship of the smaller berries) obtained by alternative pruning with these varieties.

In two of the six vintages, the citrus aroma of the Chardonnay wines was improved by minimal pruning, while mechanical pruning achieved it in one season (Fig. 14). There is a tendency that the citrus and tree fruit characters were enhanced by alternative pruning. Pruning method had no clear effect on the wine aroma of Chenin blanc (Fig. 15) and the same is true for Colombar (Fig. 16) which is also a neutral variety. Contrary to popular belief, minimal pruning enhanced the vegetative character of Sauvignon blanc wines in two of the six vintages, while it reduced the tropical fruitiness in one season (Fig. 17). The wines from the hand pruned plots showed a tendency to be fuller than that of the alternatively pruned vines. In two of the six vintages the panel of judges found a better colour in the Shiraz wines from the alternatively pruned vines (Fig.18). Except for a tendency that alternatively pruning improved quality, overall cultivar intensity, fruitiness and spiciness, no clear pattern emerged in the wines of Shiraz (Fig. 18). In four of the six vintages, there was a tendency that hand pruned vines enhanced the vegetativeness of Ruby Cabernet wine (Fig. 19). No other clear pattern emerged.
With all the varieties, especially the two reds, sunburn and millerandage were increased with alternative pruning and this tendency held true for all three trials. In all cases the bunch compaction was also reduced but no disease advantage could be monitored.

\section{CONCLUSION}

Compared to hand pruning, alternative pruning methods (mechanical, minimal and no pruning) are hugely labour saving and contribute greatly to reducing production costs of wine grapes. A prerequisite for these methods is the availability of mechanical harvest machines because hand harvesting the resultant numerous small bunches by hand, is not viable.

Alternative pruning methods reduced the vigour of all varieties used in the three different trials, but the method as well as the variety differ in the extent to which these changes took place. Vigour reduction is ascribed to shorter canes with shorter internodes and the time of shoot growth arrestment varies between varieties. Although berry mass and volume as well as physical bunch size were reduced by alternative pruning methods, resulting in lighter bunches, the increased number of bunches not only prevented a yield decrease, it was responsible for considerable yield increases compared to hand pruning. Contrary to common believe that this may affect quality, wine quality in most cases was either not affected or it was improved. Again, in this respect there are variety differences.

Cabernet Sauvignon, Pinotage and Chardonnay seemed to adapt the best to alternative pruning, while Sauvignon blanc and Merlot (both varieties prefer cooler ripening conditions) were less adaptable. The performance of Chenin blanc, Colombar, Shiraz and Ruby Cabernet was acceptable making them good candidates for alternative pruning especially when the economy is taken in account. Although not measured, practical vineyard observations showed that inner trellis posts should not be planted further apart than $6.0 \mathrm{~m}$, while additional fertilization and irrigation will be needed when anyone of the alternative pruning methods is used.

Wider vineyard rows $(3.0 \mathrm{~m}$ to $3.2 \mathrm{~m})$ must be used when one or more of the alternative pruning methods are applied to provide enough room for the expansion of the permanent vine structure. 


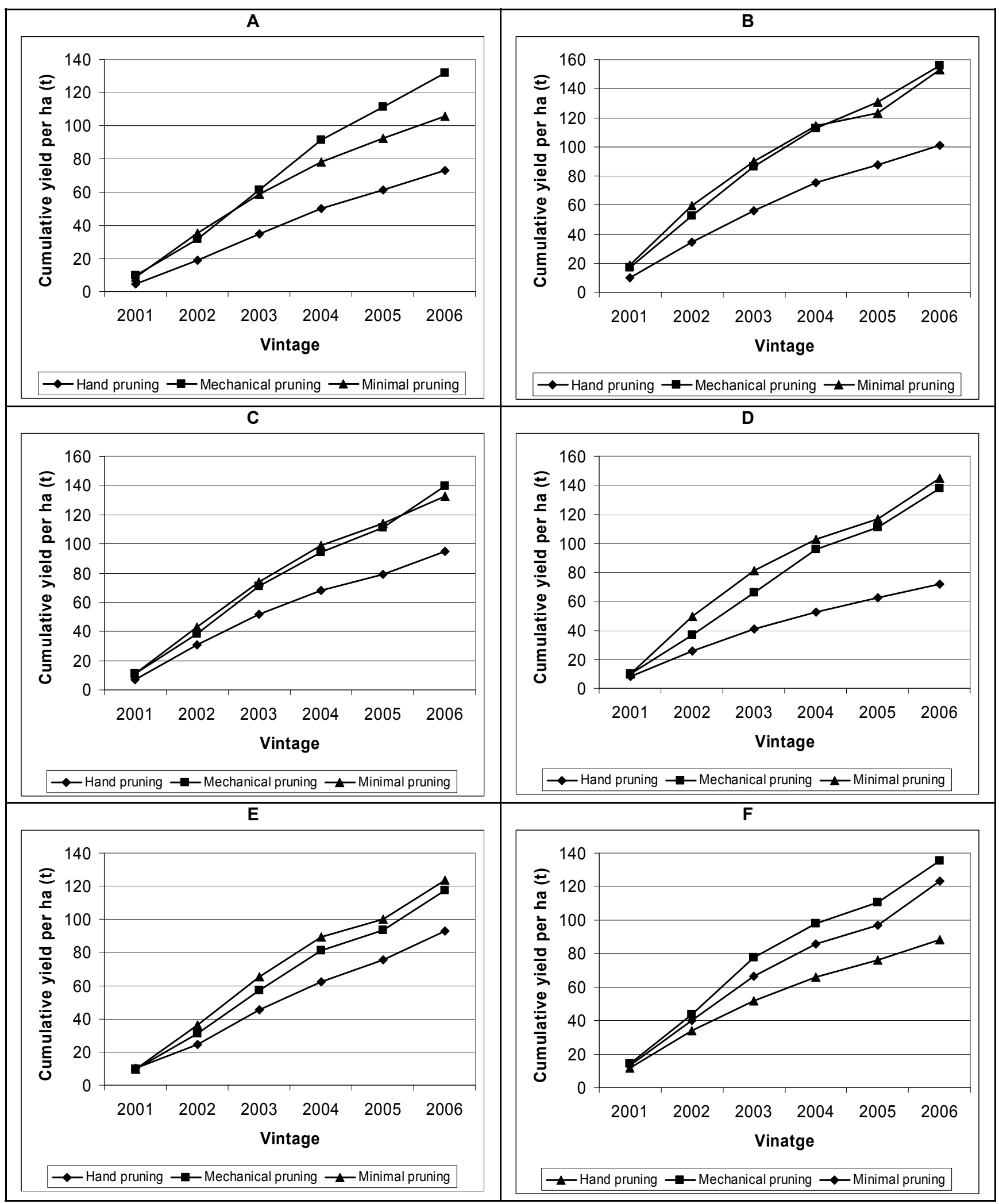

FIGURE 12

Effect of alternative pruning methods on the cumulative yield of six varieties at Robertson (2001 - 2006).

$\mathrm{A}=$ Chardonnay; $\mathrm{B}=$ Chenin blanc $; \mathrm{C}=$ Colombar; $\mathrm{D}=$ Sauvignon blanc; $\mathrm{E}=$ Ruby Cabernet and $\mathrm{F}=$ Shiraz . 


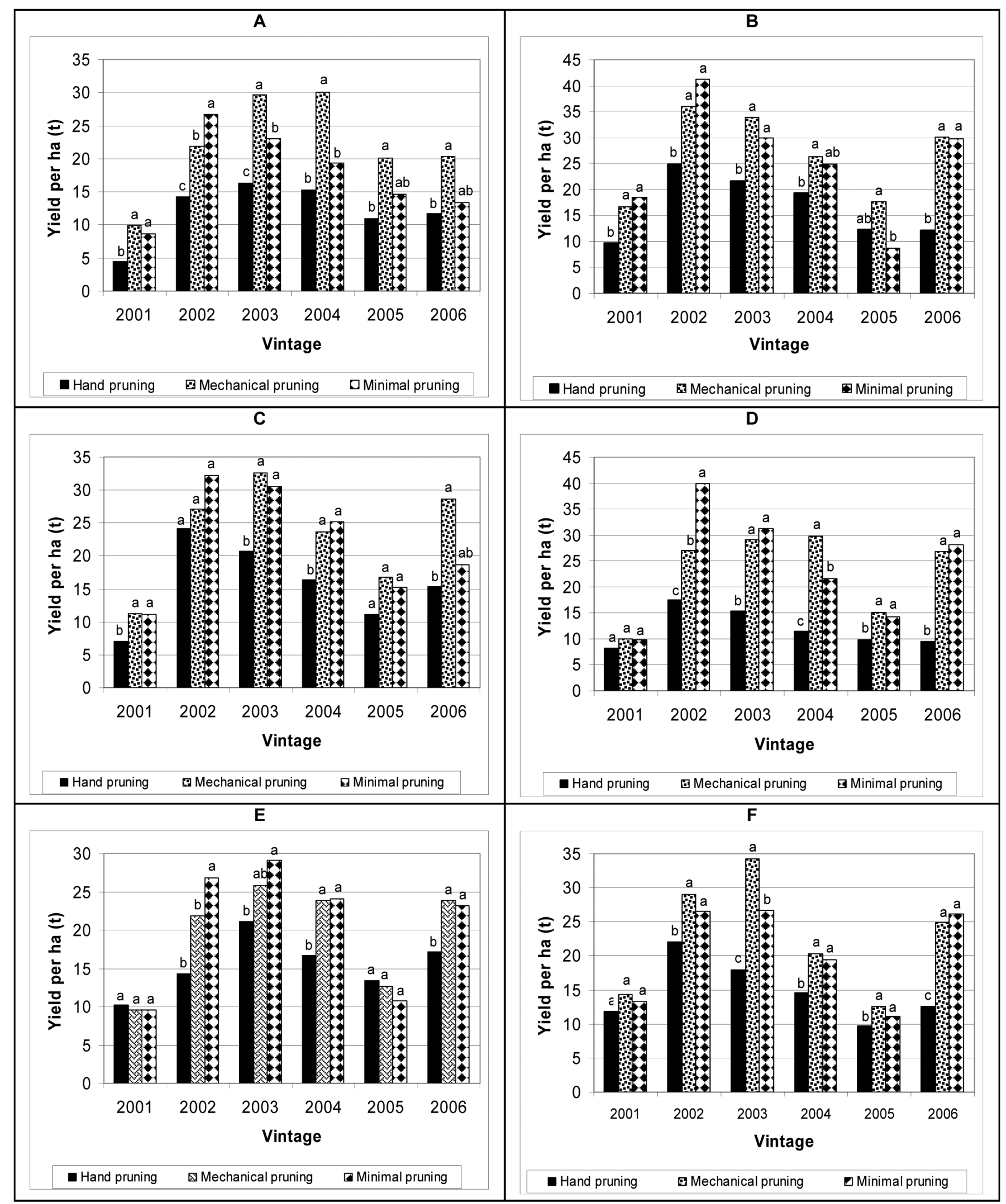

Vertical bars followed by the same letter in the same vintage do not differ significantly at $p \leq 0.05$.

FIGURE 13

Effect of alternative pruning methods on the annual yield of six varieties at Robertson (2001 - 2006). $\mathrm{A}=$ Chardonnay; $\mathrm{B}=$ Chenin blanc $\mathrm{C}=$ Colombar; $\mathrm{D}=$ Sauvignon blanc $\mathrm{E}=$ Ruby Cabernet and $\mathrm{F}=$ Shiraz. 


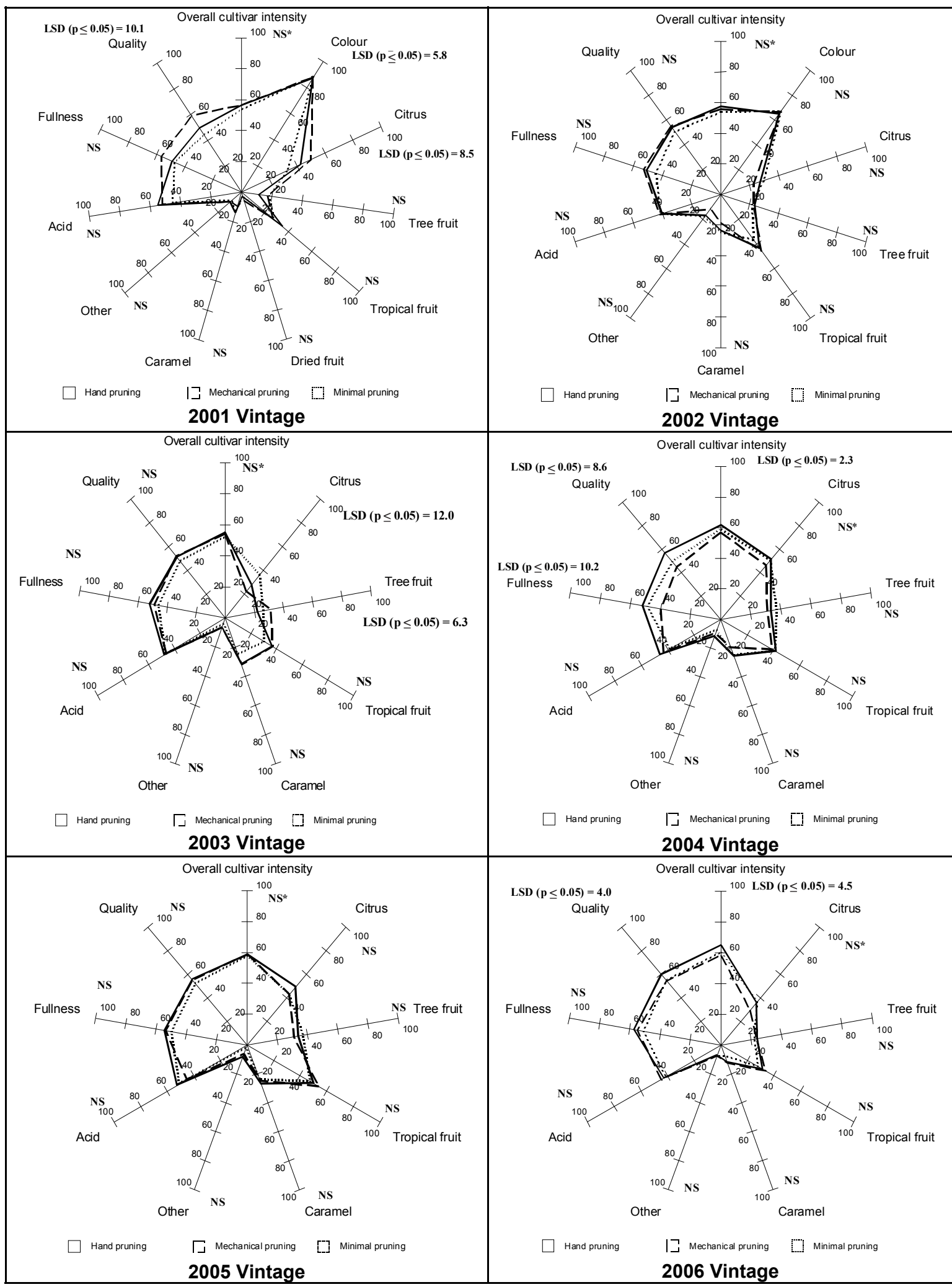

Statistical differences indicated in the figures $(p \leq 0.05)$.

${ }^{*} \mathrm{NS}=$ non significant.

FIGURE 14

Effect of pruning methods on the aroma profiles and wine quality of Chardonnay wines of six different vintages at Robertson (2001 - 2006). 


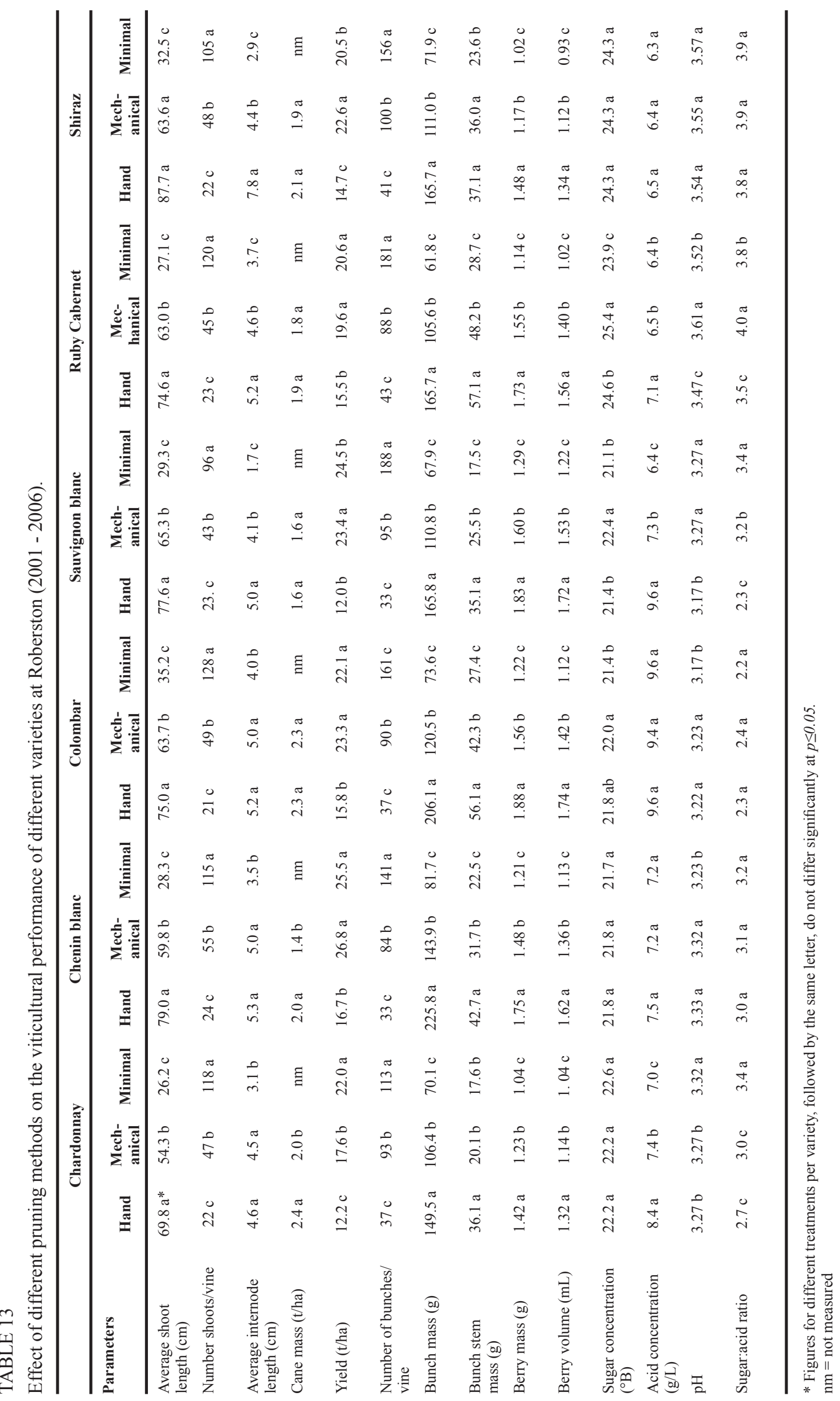


TABLE 14

Effect of pruning method on the percentage difference in relation to hand pruning for different varieties at Roberston (2001 - 2006).

\begin{tabular}{|c|c|c|c|c|c|c|c|c|c|c|c|c|}
\hline \multirow[b]{2}{*}{ Parameters } & \multicolumn{2}{|c|}{ Chardonnay } & \multicolumn{2}{|c|}{ Chenin blanc } & \multicolumn{2}{|c|}{ Colombar } & \multicolumn{2}{|c|}{ Sauvignon blanc } & \multicolumn{2}{|c|}{ Ruby Cabernet } & \multicolumn{2}{|c|}{ Shiraz } \\
\hline & $\begin{array}{l}\text { Mecha- } \\
\text { nical }\end{array}$ & Minimal & $\begin{array}{l}\text { Mecha- } \\
\text { nical }\end{array}$ & Minimal & $\begin{array}{l}\text { Mecha- } \\
\text { nical }\end{array}$ & Minimal & $\begin{array}{l}\text { Mecha- } \\
\text { nical }\end{array}$ & Minimal & $\begin{array}{l}\text { Mecha- } \\
\text { nical }\end{array}$ & Minimal & $\begin{array}{l}\text { Mecha- } \\
\text { nical }\end{array}$ & Minimal \\
\hline $\begin{array}{l}\text { Average shoot } \\
\text { length }(\%)\end{array}$ & $-21.0 \mathrm{a}$ & $-61.7 b$ & $-22.8 \mathrm{a}$ & $-63.0 \mathrm{~b}$ & $-13.5 \mathrm{a}$ & $-51.2 \mathrm{~b}$ & $-14.1 \mathrm{a}$ & $-60.9 b$ & $-15.1 \mathrm{a}$ & $-62.6 b$ & $-23.4 \mathrm{a}$ & $-59.7 b$ \\
\hline $\begin{array}{l}\text { Number shoots/ } \\
\text { vine }(\%)\end{array}$ & $110.9 \mathrm{~b}$ & $420.2 \mathrm{a}$ & $134.5 \mathrm{~b}$ & $379.8 \mathrm{a}$ & $130.5 \mathrm{~b}$ & $488.3 \mathrm{a}$ & $87.0 \mathrm{~b}$ & $314.3 \mathrm{a}$ & $97.1 \mathrm{~b}$ & $422.3 \mathrm{a}$ & $115.1 \mathrm{~b}$ & $369.2 \mathrm{a}$ \\
\hline $\begin{array}{l}\text { Average internode } \\
\text { length }(\%)\end{array}$ & $-18.8 \mathrm{a}$ & $-41.5 b$ & $-17.2 \mathrm{a}$ & $-44.9 b$ & $-8.9 \mathrm{a}$ & $-32.7 b$ & $-4.3 \mathrm{a}$ & $-42.5 b$ & $-1.1 \mathrm{a}$ & $-46.2 \mathrm{~b}$ & $-13.2 \mathrm{a}$ & $-37.6 b$ \\
\hline Cane mass $(\%)$ & $-16.7 \mathrm{a}$ & $\mathrm{nm}$ & $-30.0 \mathrm{a}$ & $\mathrm{nm}$ & $0 \mathrm{a}$ & $\mathrm{nm}$ & $0 \mathrm{a}$ & $\mathrm{nm}$ & $-5.3 \mathrm{a}$ & $\mathrm{nm}$ & $-9.5 \mathrm{a}$ & $\mathrm{nm}$ \\
\hline Yield (\%) & $91.0 \mathrm{a}$ & $56.3 \mathrm{~b}$ & $72.6 \mathrm{a}$ & $62.8 \mathrm{a}$ & $59.8 \mathrm{a}$ & $49.0 \mathrm{a}$ & $101.9 \mathrm{a}$ & $100.4 \mathrm{a}$ & $26.5 \mathrm{a}$ & $33.2 \mathrm{a}$ & $57.5 \mathrm{a}$ & $43.9 \mathrm{~b}$ \\
\hline $\begin{array}{l}\text { Number of } \\
\text { bunches/vine (\%) }\end{array}$ & $174.9 \mathrm{~b}$ & $265.3 \mathrm{a}$ & $179.5 \mathrm{~b}$ & $420.2 \mathrm{a}$ & $170.4 \mathrm{~b}$ & $370.6 \mathrm{a}$ & $206.0 \mathrm{~b}$ & $477.3 \mathrm{a}$ & $113.6 \mathrm{~b}$ & $327.9 \mathrm{a}$ & $153.6 \mathrm{~b}$ & $295.9 \mathrm{a}$ \\
\hline $\begin{array}{l}\text { Bunch mass } \\
(\%)\end{array}$ & $-27.1 \mathrm{a}$ & $-50.9 \mathrm{~b}$ & -35.7 a & $-64.2 b$ & $-34.0 \mathrm{a}$ & $-60.5 b$ & $-30.4 \mathrm{a}$ & $-56.9 b$ & $-33.5 \mathrm{a}$ & $-60.4 b$ & $-29.8 \mathrm{a}$ & $-55.4 b$ \\
\hline $\begin{array}{l}\text { Berry mass } \\
(\%)\end{array}$ & $-13.2 \mathrm{a}$ & $-26.4 b$ & $-14.6 \mathrm{a}$ & $-29.9 b$ & $-16.5 \mathrm{a}$ & $-35.4 \mathrm{~b}$ & $-12.8 \mathrm{a}$ & $-29.9 b$ & $-9.5 \mathrm{a}$ & $-33.0 \mathrm{~b}$ & $-20.8 \mathrm{a}$ & $-31.1 b$ \\
\hline $\begin{array}{l}\text { Berry volume } \\
(\%)\end{array}$ & $-13.0 \mathrm{a}$ & $-25.1 \mathrm{~b}$ & $-15.0 \mathrm{a}$ & $-29.4 \mathrm{~b}$ & $-17.5 \mathrm{a}$ & $-35.7 b$ & $-10.8 \mathrm{a}$ & $-29.1 \mathrm{~b}$ & $-9.2 \mathrm{a}$ & $-32.5 b$ & $-15.9 \mathrm{a}$ & $-30.1 b$ \\
\hline
\end{tabular}

* Figures for different treatments per variety, followed by the same letter, do not differ significantly at $p \leq 0.05$. $\mathrm{nm}=$ not measured. 


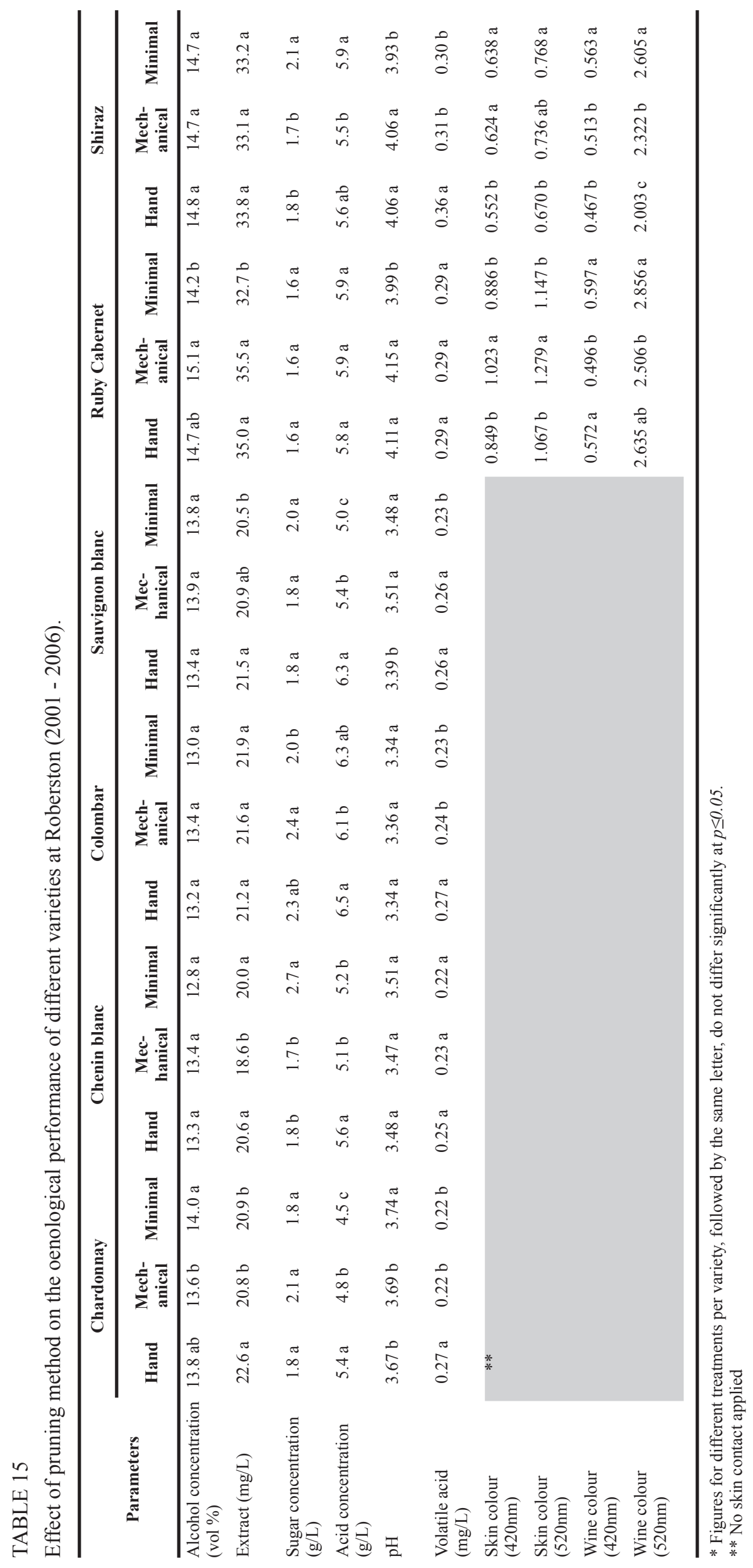




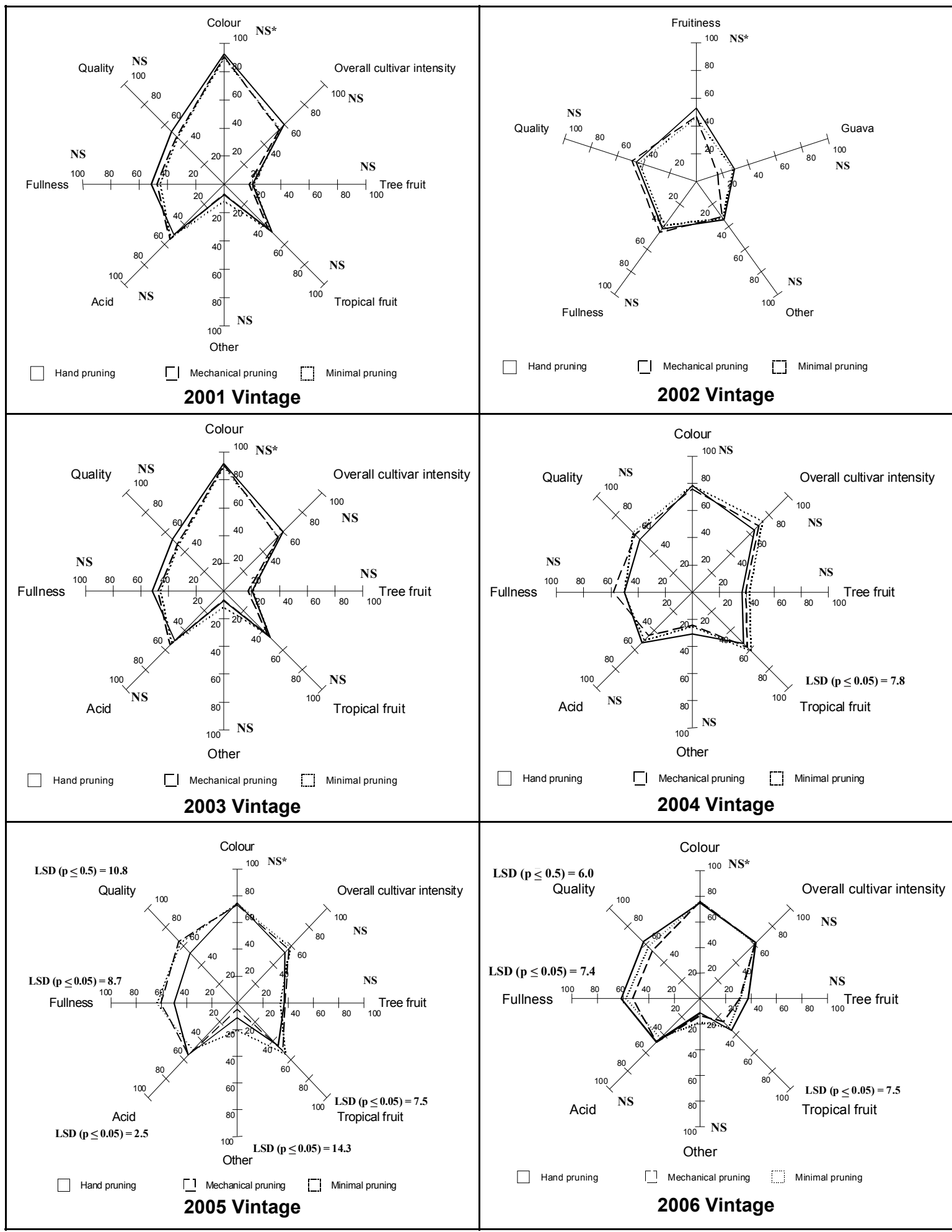

Statistical differences indicated in the figures $(p \leq 0.05)$.

${ }^{*} \mathrm{NS}=$ non significant

FIGURE 15

Effect of pruning methods on the aroma profiles and wine quality of Chenin blanc wines of six different vintages (2001 - 2006). 


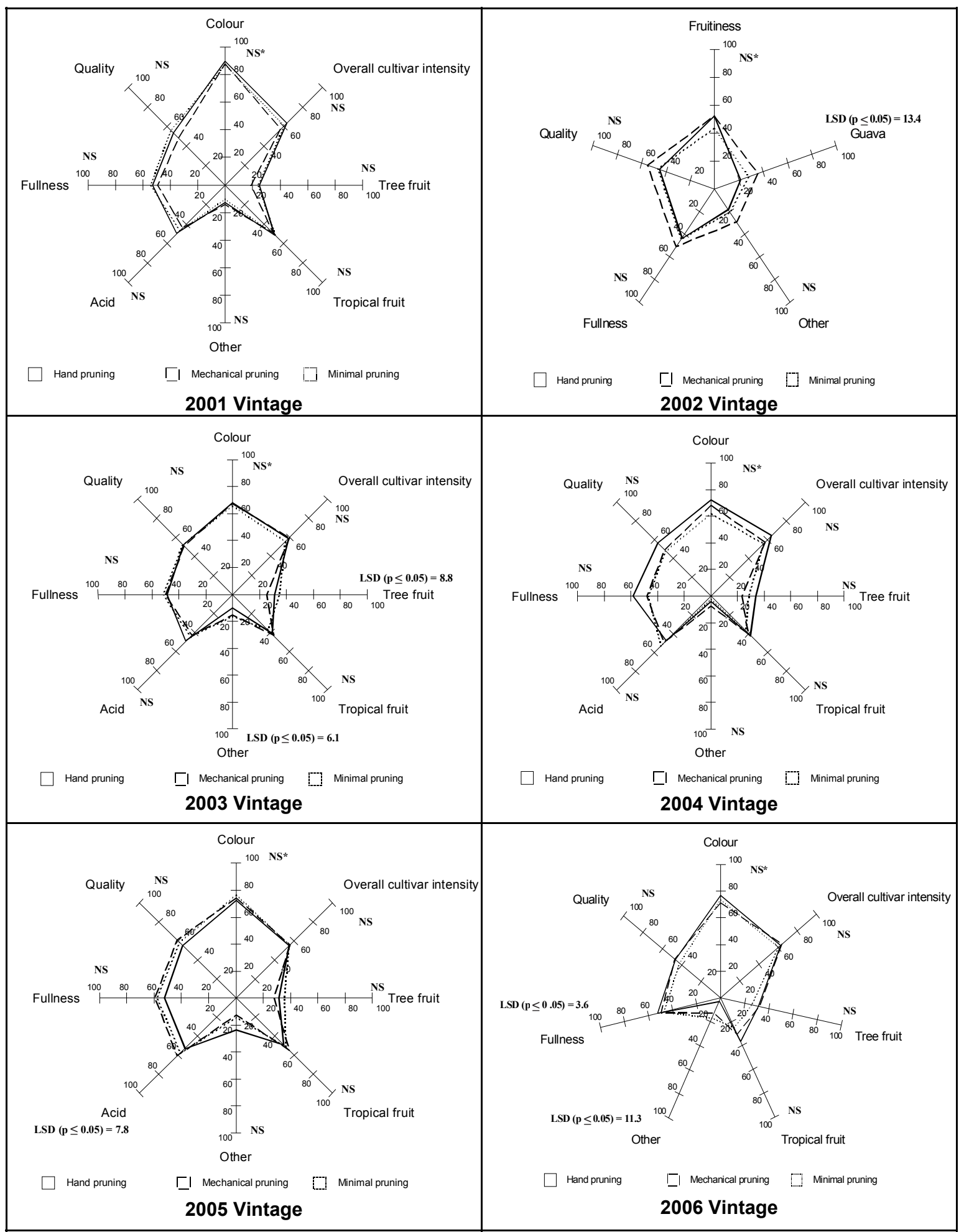

Statistical differences indicated in the figures $(p \leq 0.05) . \quad \quad{ }^{*} \mathrm{NS}=$ non significant.

FIGURE 16

Effect of pruning methods on the aroma profiles and wine quality of Colombar wines of six different vintages at Robertson (2001 - 2006) 


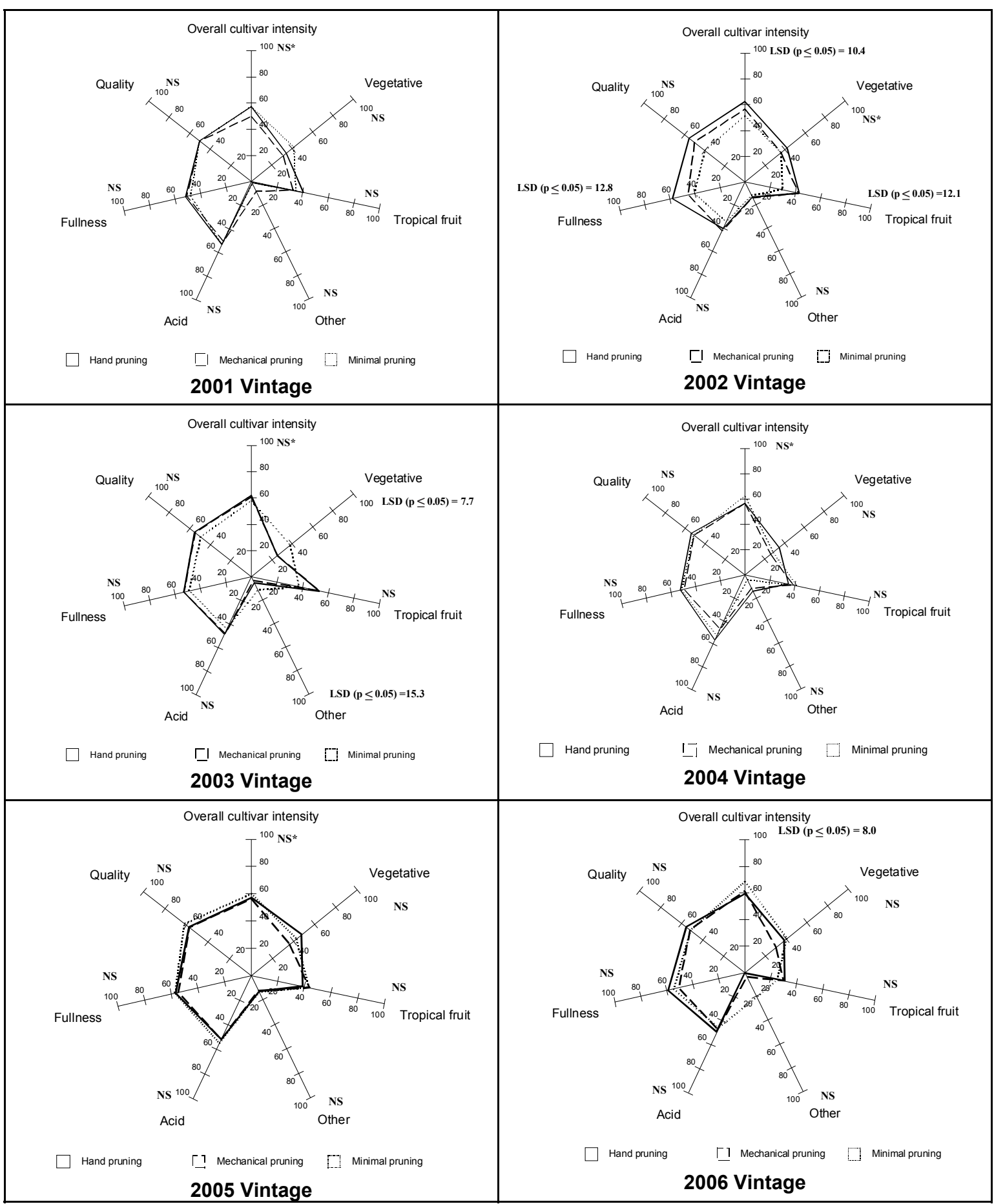

Statistical differences indicated in the figures $(p \leq 0.05)$.

${ }^{*} \mathrm{NS}=$ non significant

FIGURE 17

Effect of pruning methods on the aroma profiles and wine quality of Sauvignon blanc wines of six different vintages at Robertson (2001 - 2006). 




Statistical differences indicated in the figures $(p \leq 0.05)$.

${ }^{\star} \mathrm{NS}=$ non significant

\section{FIGURE 18}

Effect of pruning methods on the aroma profiles and wine quality of Shiraz wines of six different vintages at Robertson (2001 - 2006). 


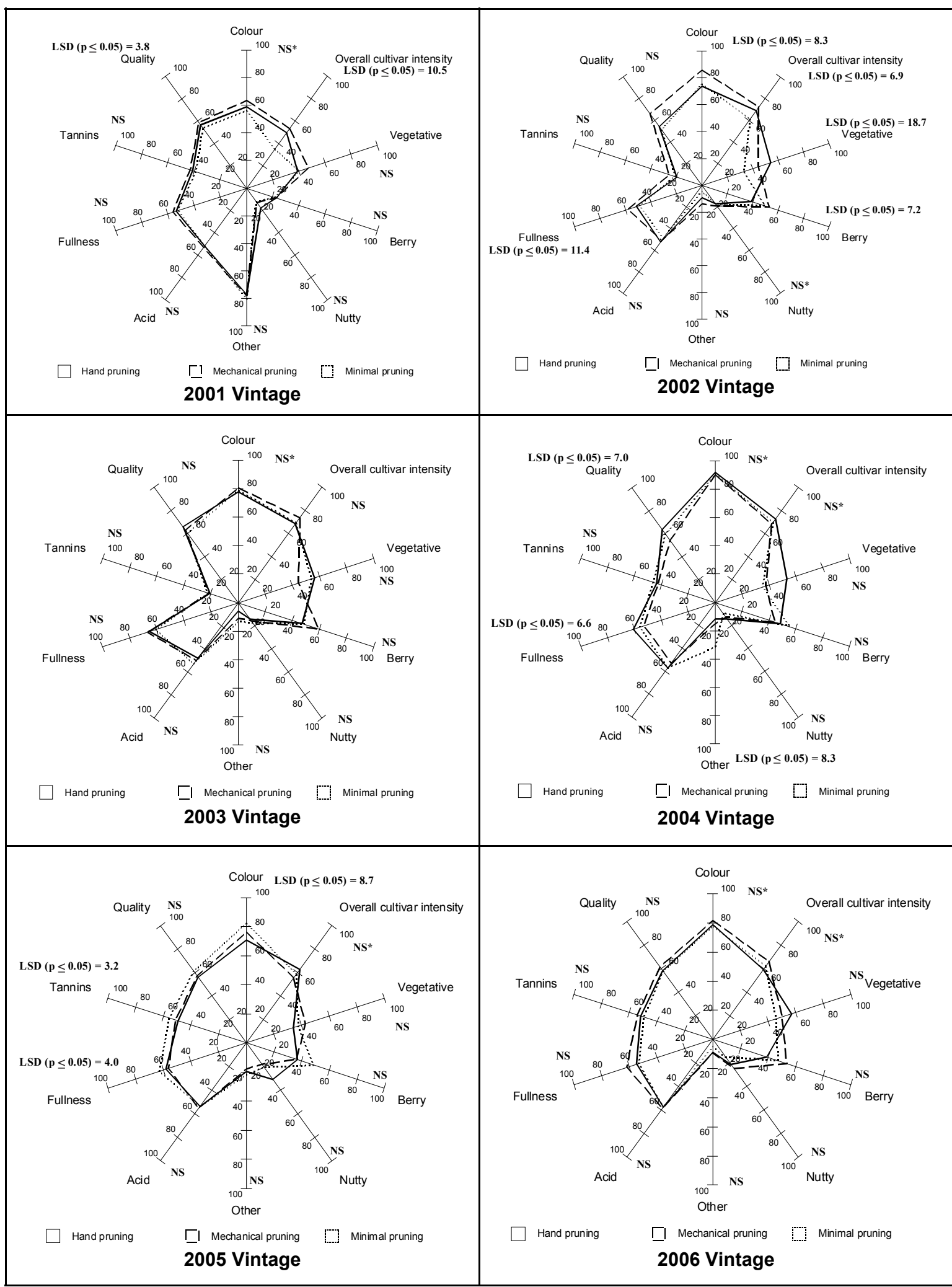

Statistical differences indicated in the figures $(p \leq 0.05)$.

${ }^{*} \mathrm{NS}=$ non significant.

FIGURE 19

Effect of pruning methods on the aroma profiles and wine quality of Ruby Cabernet wines of six different vintages at Robertson (2001 - 2006). 


\section{LITERATURE CITED}

Anderson, P.C., Sims, C.A. \& Harrison, J.M., 1996. Influence of simulated mechanized pruning and hand pruning on yield and berry composition of Vitis rotundifolia Noble and Welder. Am. J. Enol. Vitic. 47, 292 - 296.

Archer, E., 1999. Meganisering van snoei by wingerd: Vereistes gestel aan die wingerd en reaksie van wingerdstok. Wynboer Tegnies 117, 46-48.

Archer, E. \& Van Schalkwyk, D., 1998. Die omskakeling van die prieelstelsel sowel as wingerdstokke vir meganiese snoei van wyndruiwe. Wynboer Tegnies $102,10-11$

Bakonyi, I., 1987. Non-pruning: a new technique in vineyard management. Austr. Grapegrower \& Winemaker 280, 112 - 113 .

Cirami, R.M., McCarthy, M.G. \& Furkaliev, D.G., 1985. Minimum pruning of Shiraz vines - effects on yield and wine colour. Austr. Grapegrower \& Winemaker 263, $24-26$.

Clingeleffer, P.R., 1988. Response of Riesling clones to mechanical hedging and minimal pruning of cordon trained vines - implications for clonal selection. Vitis $27,87-83$

Clingeleffer, P.R., 1989. Update: Minimal pruning of cordon trained vines. Austr. Grapegrower \& Winemaker 282, $78-83$

Clingeleffer, P.R., 1993. Vine response to modified pruning practices. In: R.M. Pool (ed). Pruning mechanization and crop control. Proc. $2^{\text {nd }}$ Nelson J. Shaulis Gr. Symp., July 13 - 14, Fredonia New York, 20 -30.

Clingeleffer, P.R., \& Possingham, J.V., 1987. The role of minimal pruning of cordon trained vines in canopy management and its adoption in Australian viticulture. Austr. Grapegrower \& Winemaker 280, 7 - 11 .

Clingeleffer, P.R. \& Krake, L.R., 1992. Responses of Cabernet franc grapevines to minimal pruning and virus infection. Am. J. Enol. Vitic. 43, $31-37$.

d'Armailhacq, A., 1867. De la culture des vinges dans le Médoc. 3me ed. P. Chaumas, Libraire-éditeur, Fossés du Chapeau-Rouge, 34 Bordeaux.

Hunter, J.J., De Villiers, O.T. \& Watts, J.E., 1991. The effect of partial defoliation on quality characteristics of Vitis vinifera L. cv. Cabernet Sauvignon grapes. II. Skin color, skin sugar, and wine quality. Am. J. Enol. Vitic. 42, 13 -18.

May, P. \& Clingeleffer, P.R., 1977. Mechanical pruning of grapevines. Austr. Wine Brew. Spirit Rev. 96 (11), $36-38$
Martinez de Toda, F. \& Sancha, J.C., 1988. Long-term effects of zero pruning on Grenache vines under drought conditions. Vitis 37, $155-157$.

McCarthy, M.G. \& Cirami, R.M., 1990. Minimal pruning effects on the performance of selections of four Vitis vinifera cultivars. Vitis 29, 85-96.

Morris, J.R., Cawthon, D.L., \& Fleming, J.W., 1975. Effect of mechanical pruning on yield and quality of Concord grapes. Ark. Farm. Res. 24(3), 12.

Morris, J.R.\& Cawthon, D.L., 1980. Mechanical pruning and node adjustment of cordon trained Concord grapevines. J. Am. Soc. Hort. Sci. 105, 310 - 313.

Morris, J.R. \& Cawthon, D.L., 1981. Yield and quality response of Concord grapes (Vitis Labrusca L.) to mechanized vine pruning. Am. J. Enol. Vitic. 32, $280-282$.

Reynolds, A.G., 1988. Response of Okanagan Riesling vines to training system and simulated mechanical pruning. Am. J. Enol. Vitic. 39, $205-212$.

Reynolds, A.G. \& Wardle, D.A., 1993. Yield component path analysis of Okanagan Riesling vines conventionally pruned or subjected to simulated mechanical pruning. Am. J. Enol. Vitic. 44, 173 - 179.

Ribénreau-Gayon, P., Glories, Y., Maujean, A. \& Dubourdieu, D., 2000. The chemistry of wine and stabilization and treatments. In: John Wiley \& Sons Ltd.. Handbook for Enology, Vol. 2. 129 - 185

Rühl, E.H. \& Clingeleffer, P.R., 1993. Effect of minimal pruning and virus inoculation on the carbohydrate and nitrogen accumulation in Cabernet franc vines. Am. J. Enol. Vitic. 44, $81-85$.

Saayman, D., 1981. Klimaat, grond en wingerdbougebiede. In: J. Burger \& J. Deist (reds), Wingerdbou in Suid-Afrika, $48-66$.

Shaulis, N.J., Pollock, J., Crowe, D.E. \& Shepardson, E.S., 1975. Mechanical pruning of grapevines: progress 1968 - 1972. Proc. New. York State Hort.. Sci. 118, $61-69$.

Soil Classification Work Group, 1991. Soil classification - A taxonomic system for South Africa. Memoirs on natural resources of South Africa no. 15. Dept. Agric. Developm., Pretroria.

Van Schalkwyk, D., 2004. Metodes om korrelmassa, korrelvolume en trosmassa te bepaal. Wynboer 182, $115-116$.

Zeeman, A.S., 1981. Oplei. In: J. Burger \& J. Deist (reds), Wingerdbou in SuidAfrika, 185 - 201. 